\title{
Substituent effect on cyclopalladation of arylimines
}

\author{
Chuan-Lin Chen, Yi-Hung Liu, Shie-Ming Peng, Shiuh-Tzung Liu * \\ Department of Chemistry, National Taiwan University, 1, Section 4, Roosevelt Road, Taipei 106, Taiwan, ROC
}

Received 1 October 2003; accepted 2 March 2004

\begin{abstract}
The substituent effect on cyclopalladation of a series of substituted benzylidene-arylamines $\left[\left(\mathrm{R}_{2} \mathrm{C}_{6} \mathrm{H}_{3}\right) \mathrm{N}=\mathrm{CCH}_{2}(\mathrm{ArX})\right.$, where $\mathrm{R}=\mathrm{H}, \mathrm{Me}, i$-Pr, $\mathrm{OH} ; \mathrm{X}_{n}=\mathrm{H}$; 3,5-dimethoxyl; 3,5-difloro; 3,5-bis(2,6-dimethoxyphenyl); 4-chloro; 2-bromo; 2,4,6-trimethyl] by palladium(II) chloride under basic conditions was studied. As expected, cyclometallation takes place at the ortho position of the aryl ring resulting in formation of a five-member chelate ring. All metallated products have in chloro-bridged dipalladium $\left[\mathrm{Pd}_{2} \mathrm{Cl}_{2}\right]$ structures except the one with $\mathrm{R}=\mathrm{OMe}$. A palladium species with mixed bridging ligand $\left[\mathrm{Pd}_{2}(\mathrm{OH}) \mathrm{Cl}\right]$ was isolated due to the hydrogen-bonding interaction through the hydroxy ligand and the methoxy substituents. For the $t$-butyl substituted arylimine, cyclometallation does not occur because of the steric reason. In the case of $\mathrm{R}=\mathrm{OH}, \mathrm{X}_{n}=2,4,6$-trimethyl, the cyclopalladation occurred at the benyzlic position forming a tetrameric palladium species. All the palladium complexes were characterized by both spectral and/or crystal structural analyses.
\end{abstract}

(C) 2004 Elsevier B.V. All rights reserved.

Keywords: Cyclopalladation; Arylimine; $\mathrm{C}-\mathrm{H}$ activation

\section{Introduction}

Among the various examples of intramolecular $\mathrm{C}-\mathrm{H}$ activation via transition metal complexes, cyclopalladation of benzylidene-arylamine ligands is the one with extensively studied [1-6]. It is known that such palladation preferentially occurs at the carbon center, which would tend to form a five-membered ring, and at $\mathrm{sp}^{2}$ hybridized $\mathrm{C}-\mathrm{H}$ bonds. In terms of the electronic effect, substituents on both the nitrogen center and the aromatic ring affect the rate of metallation [6]. Although many studies involving cyclopalladation of the substituted benzylidenearylamines are presented in the literature [2-6], few are in the investigation of bulky and donative substituents on both aromatic systems [1c,2a]. Here we report the cyclopalladation reactions of a wide variety of substituted benzylidene-dialkylarylamines $\mathbf{L}_{n}$ with $\left(\mathrm{CH}_{3} \mathrm{CN}\right)_{2} \mathrm{PdCl}_{2}$ under basic conditions.

\footnotetext{
${ }^{*}$ Corresponding author. Tel.: +886-2-2366-0352; fax: +886-2-23636359.

E-mail addresses: stliu@ccms.ntu.edu.tw, stliu@ntu.edu.tw (S.-T.
}
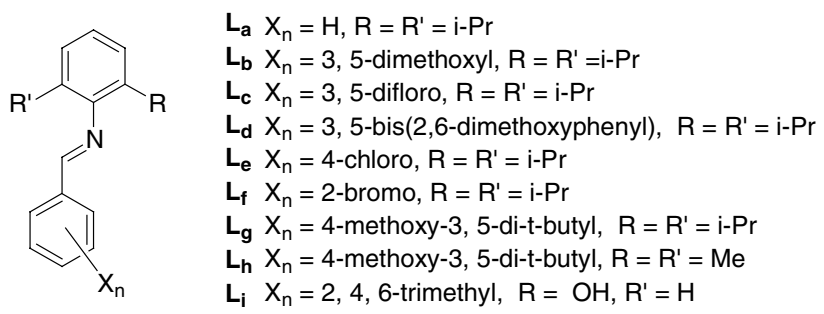

\section{Results and discussion}

\subsection{Preparation of ligands}

Condensation reaction of aniline derivatives with an excess of the corresponding substituted bezaldehyde in methanol provided the desired ligands in good yields upon chromatography, whereas the aldehydes used for the preparation of $\mathbf{L}_{\boldsymbol{x}}(\boldsymbol{x}=\mathbf{d}$, i) were prepared accordingly to the literature procedure (see Section 4). Characterizations of this series of compounds were performed by spectral and elemental analyses. Selected 
Table 1

Spectral data for ligands $\mathbf{L}_{\mathbf{a}}-\mathbf{L}_{\mathbf{i}}$

\begin{tabular}{lllll}
\hline Ligands & IR $v_{\mathrm{C}=\mathrm{N}}\left(\mathrm{cm}^{-1}\right)$ & \multicolumn{2}{l}{${ }^{1} \mathrm{H} N M R$} & \\
\cline { 3 - 4 } & & ${ }^{13} \mathrm{C} N M R-C=\mathrm{N}-$ \\
\hline $\mathbf{L}_{\mathbf{a}}$ & 1646 & 7.90 & 8.20 & 162.0 \\
$\mathbf{L}_{\mathbf{b}}$ & 1604 & 7.07 & 8.11 & 161.9 \\
$\mathbf{L}_{\mathbf{c}}$ & 1595 & 7.42 & 8.11 & 159.5 \\
$\mathbf{L}_{\mathbf{d}}$ & 1635 & 7.88 & 8.23 & 162.5 \\
$\mathbf{L}_{\mathbf{e}}$ & 1640 & 7.83 & 8.14 & 160.6 \\
$\mathbf{L}_{\mathbf{f}}$ & 1632 & 8.25 & 8.56 & 161.4 \\
$\mathbf{L}_{\mathbf{g}}$ & 1645 & 7.79 & 8.09 & 162.7 \\
$\mathbf{L}_{\mathbf{h}}$ & 1646 & 7.88 & 8.20 & 162.7 \\
$\mathbf{L}_{\mathbf{i}}$ & 1630 & 7.59 & 9.10 & 157.7 \\
\hline
\end{tabular}

spectral data are summarized in Table 1. Infrared absorption near $1600 \mathrm{~cm}^{-1}$ is a characteristic stretching frequency for $\mathrm{C}=\mathrm{N}$. In addition, the imine carbon shift $(\sim 160 \mathrm{ppm})$ in the ${ }^{13} \mathrm{C}$ NMR is further evidence to support the existence of this structure. The ${ }^{1} \mathrm{H}$ NMR chemical shifts appeared in the range of $8-9$ ppm are typical for the imino protons $(-\boldsymbol{H C}=\mathrm{N})$. It is noticed that a long-range ${ }^{19} \mathrm{~F}$ coupling is observed in compound $\mathbf{L}_{\mathbf{c}}$. Thus the ${ }^{13} \mathrm{C}$ NMR signal of imino-carbon appears as a triplet at $159.6 \mathrm{ppm}$ with ${ }^{4} J_{\mathrm{C}-\mathrm{F}}=3 \mathrm{~Hz}$.

\subsection{Cyclopalladtion}

To a mixture of $\left(\mathrm{CH}_{3} \mathrm{CN}\right)_{2} \mathrm{PdCl}_{2}$, sodium acetate and the ligands $\mathbf{L}_{\mathbf{a}}-\mathbf{L}_{\mathbf{f}}$ in tetrahydrofuran were stirred at ambient temperature for $38 \mathrm{~h}$ and the desired cyclopalladtion products were isolated as stable solids upon crystallization (Eq. (1)). All products were characterized by spectral methods and some of them are further confirmed by single-crystal structural analysis. Selected spectral data of cyclopalladated product with this series of ligands are summarized in Table 2. In all instances, the cyclopalladation readily occurs at ortho position of the benzal ring to form an endo five membered chelate ring and the products having a chloro-bridged dipalladium

Table 2

Selected spectral data of complexes

\begin{tabular}{|c|c|c|c|}
\hline Compound & $\mathrm{IR}^{\mathrm{a}} v_{\mathrm{C}=\mathrm{N}}$ & $\begin{array}{l}{ }^{1} \mathrm{H} \mathrm{NMR}{ }^{\mathrm{b}} \\
-\boldsymbol{H C}=\mathrm{N}-\end{array}$ & $\begin{array}{l}{ }^{13} \mathrm{C} \text { NMR } \\
-\mathrm{H} C=\mathrm{N}-\end{array}$ \\
\hline $\mathbf{1}_{\mathrm{a}}$ & 1603 & 7.72 & 176.2 \\
\hline$C i s-\mathbf{1}_{\mathbf{b}}$ & 1586 & 7.56 & 176.0 \\
\hline Trans $-\mathbf{1}_{\mathbf{b}}$ & 1584 & $7.66 ; 7.63$ & $177.2 ; 177.0$ \\
\hline Trans $-\mathbf{1}_{\mathbf{c}}$ & 1570 & $7.70 ; 7.67$ & $176.6 ; 176.4$ \\
\hline $\mathbf{1}_{\mathrm{d}}$ & 1591 & 7.61 & 176.9 \\
\hline $\mathbf{1}_{\mathrm{e}}$ & 1602 & 7.70 & 175.4 \\
\hline $\mathbf{1}_{\mathrm{f}}$ & 1588 & 8.10 & c \\
\hline $3_{g}$ & 1612 & 9.41 & 176.1 \\
\hline $3_{\mathrm{h}}$ & 1610 & 9.24 & 176.0 \\
\hline $33_{\mathrm{h}}^{\prime}$ & 1613 & 8.81 & 173.8 \\
\hline $7_{i}$ & 1595 & 8.05 & 163.7 \\
\hline
\end{tabular}

structure, which is consistent with the related works under the similar conditions reported in the literature [1,2]. Although cis and trans isomers are possible in the chlorobridged palladium dimers, complexes $\mathbf{1}_{\mathbf{a}}, \mathbf{1}_{\mathfrak{c}}, \mathbf{1}_{\mathbf{d}}$ and $\mathbf{1}_{\mathbf{f}}$ were formed in the trans configuration. Interestingly, a pair of products cis- $\mathbf{1}_{\mathbf{b}}$ and trans $-\mathbf{1}_{\mathbf{b}}$ were obtained when $\mathbf{L}_{\mathbf{b}}$ was used. Both cis- $\mathbf{1}_{\mathbf{b}}$ and trans $-\mathbf{1}_{\mathbf{b}}$ were obtained in 1:1 ratio upon the extraction of reaction products with a mixture of dichloromethane/water. However, only the trans $-\mathbf{1}_{\mathbf{b}}$ was yielded when the $n$-hexane was used as the extraction solvent. The dipalladium metal center in trans$\mathbf{1}_{b}$ remains as di-chloro brideged core, but hydroxy and chloride become the bridging ligands between two metal center in the cis-1 $\mathbf{1}_{\mathbf{b}}$ as confirmed by spectral and crystallographic analyses (see below).<smiles>[Y2]c1cccc(/C=N/c2c([R])cccc2[R])c1</smiles><smiles></smiles>
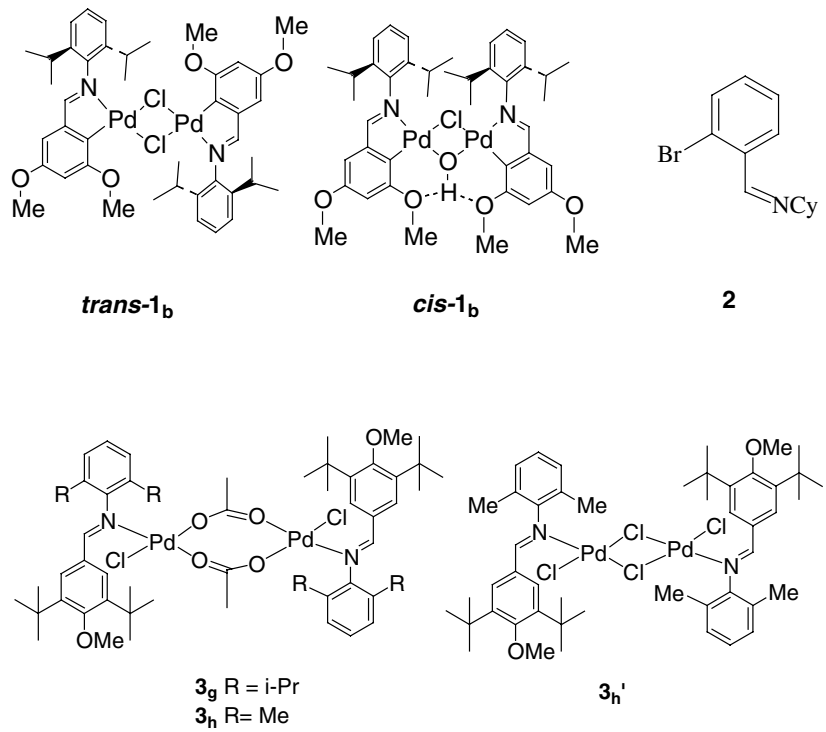

Notably, the $o$-metallation of $\mathrm{C}-\mathrm{H}$ bond took place preferentially over the oxidative addition of $\mathrm{C}-\mathrm{Br}$ bond in $\mathbf{L}_{\mathbf{f}}$ as evidenced by the NMR spectroscopic study. The chemical shift corresponding to the ortho proton $(\delta 8.25)$ in the free ligand $\mathbf{L}_{\mathbf{f}}$ disappeared after the reaction with the appearance of three distinct aromatic resonances in 


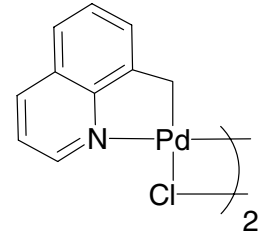

4

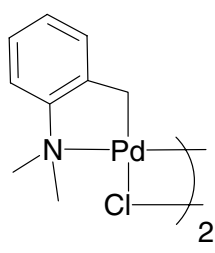

5

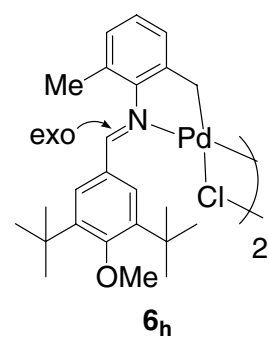

Fig. 1. $\mathrm{C}-\mathrm{H}$ activation at benzylic position.

${ }^{1} \mathrm{H}$ NMR of the complex, indicating that the $\mathrm{C}-\mathrm{H}$ activation at aromatic ring has occurred. This outcome is quite similar to that reported by Vila et al. [7] in the metallation of 2 .

Reaction of bulky ligands $\mathbf{L}_{\mathbf{g}}$ and $\mathbf{L}_{\mathbf{h}}$ with $\left(\mathrm{CH}_{3} \mathrm{CN}\right)_{2} \mathrm{PdCl}_{2}$ in the presence of sodium acetate provides a simple substitution product $\mathbf{3}_{\mathbf{g}-\mathbf{h}}$ without the formation of any cyclometallated product. The tertiary butyl group at meta position of benzylimine readily hindered the $\mathrm{C}-\mathrm{H}$ activation at ortho position. By contrast with the findings that the cyclopalladation occurred with methylquinoline or methylaniline to form $\mathbf{4}$ and $\mathbf{5}$, respectively [8], we noticed that the metallation did not occur at benzylic position of $\mathbf{L}_{\mathbf{h}}$ to provide $\mathbf{6}_{h}$, presumably due to the energically unfavorable five-exo chelate ring (Fig. 1). Most of the cyclopalladated complexes in this work were isolated as chloro-bridging dinuclear species, but complex $\mathbf{3}_{\mathbf{h}}$ was in the form of both aceto- and chloro-bridged ones. However, there were no products with mixed bridged ligands formed from this reaction.

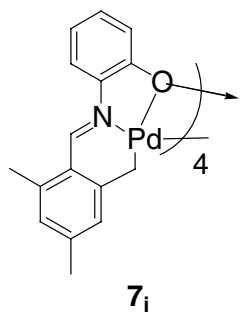

In case of ligand $\mathbf{L}_{\mathbf{i}}$, cyclopalladation took place at benzylic position with the coordination phenolate-oxygen toward the metal center as evidenced by its ${ }^{1} \mathrm{H}$ NMR. The appearance of two sets of doublets at 3.40 and 2.52 with integration of $1 \mathrm{H}$ each clearly indicated the formation $\mathrm{Pd}-\mathrm{C}$ via $\mathrm{C}-\mathrm{H}$ activation. This $\mathrm{C}-\mathrm{H}$ activation is favored by the formation of a six-endo chelate ring unlike the imine $\mathbf{L}_{\mathbf{h}}$. Instead of di-palladium complex, the cyclopalladated product $\mathbf{7}_{\mathbf{i}}$ forms a tetra-nuclear species via the coordination of an oxygen donor as evidenced by its crystal structure.

\subsection{Structural characterization}

Both the red-shift of stretching frequency on $\mathrm{C}=\mathrm{N}$ and the positive coordination shift of imine-proton
(Table 2) clearly indicate the coordination of imine toward the metal center. For the palladation products $\mathbf{1}_{\mathbf{a}-\mathbf{f}}$, the disappearance of the ortho aromatic proton on the ${ }^{1} \mathrm{H}$ NMR spectrum clearly demonstrates that $\mathrm{C}-\mathrm{H}$ activation occurred at that site. For those with isopropyl substitutents, the methyl groups on the ${ }^{1} \mathrm{H}$ NMR spectrum appear a doublet in the free ligands, but split into two sets of doublets upon cyclometallation, which is presumably due to the hindered rotation of that group. The dimeric structure of the bridging chloro ligand of these species as well as the stereochemistry of $\mathbf{1}_{\mathbf{b}}$ is further confirmed by their single-crystal structure determination, which is consistent with most of the related complexes reported [3].

Single crystals of complex $\mathbf{1}_{\mathbf{a}}$ were grown by re-crystallization from $\mathrm{CH}_{2} \mathrm{Cl}_{2} /$ hexane at ambient temperature. An ORTEP diagram for $\mathbf{1}_{\mathbf{a}}$ is shown in Fig. 2. Crystallographic data are summarized in Table 5; selected bond distances and bond angles are shown in Table 3 . In the complex $\mathbf{L}_{\mathbf{a}}$ ligand is bonded to the di- $\mu$-chlorobridge unit through the nitrogen and an aromatic carbon atom providing a five-membered chelate ring. Structural data for $\mathbf{1}_{\mathbf{a}}$ show that the coordination geometry about the palladium atom is slightly distorted from square plane with the two imino ligands in trans

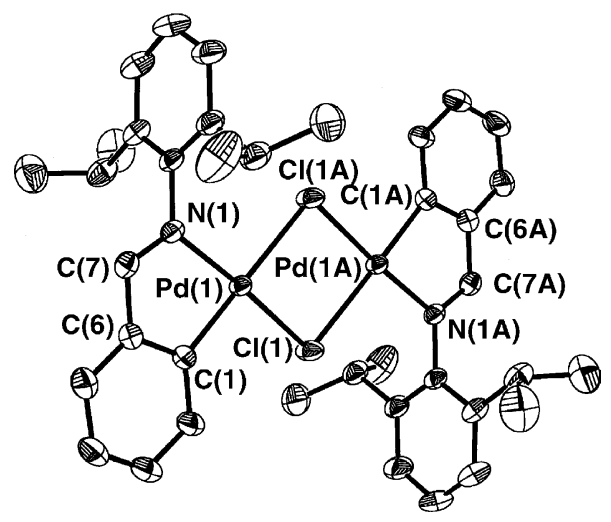

Fig. 2. ORTEP plot of $\mathbf{1}_{\mathbf{a}}$.

Table 3

Selected bond distances $(\AA)$ and bond angles $\left(^{\circ}\right)$

\begin{tabular}{lccc}
\hline Complex & $\mathbf{1}_{\mathbf{a}}$ & trans $\mathbf{1}_{\mathbf{b}}$ & $\mathbf{1}_{\mathbf{d}}$ \\
\hline $\mathrm{Pd}(1)-\mathrm{N}(1)$ & $2.022(1)$ & $2.021(2)$ & $2.042(2)$ \\
$\mathrm{Pd}(1)-\mathrm{C}(1)$ & $1.965(2)$ & $2.007(3)$ & $2.016(3)$ \\
$\mathrm{C}(7)-\mathrm{N}(1)$ & $1.279(2)$ & $1.286(3)$ & $1.278(4)$ \\
$\mathrm{Pd}(1)-\mathrm{Cl}(1)$ & $2.3255(5)$ & $2.3248(7)$ & $2.3285(8)$ \\
$\mathrm{Pd}(1)-\mathrm{Cl}(1 \mathrm{~A})$ & $2.4506(5)$ & $2.4208(7)$ & $2.4333(8)$ \\
$\mathrm{Pd}(1 \mathrm{~A})-\mathrm{Cl}(1 \mathrm{~A})$ & $2.3255(5)$ & $2.3248(7)$ & $2.3285(8)$ \\
$\mathrm{Pd}(1) \cdots \operatorname{Pd}(1 \mathrm{~A})$ & 3.457 & 3.503 & 3.545 \\
$\mathrm{~N}(1)-\mathrm{Pd}(1)-\mathrm{C}(1)$ & $81.13(7)$ & $80.91(9)$ & $81.6(1)$ \\
$\mathrm{N}(1)-\mathrm{Pd}(1)-\mathrm{Cl}(1)$ & $176.10(4)$ & $177.47(6)$ & $177.51(7)$ \\
$\mathrm{N}(1)-\mathrm{Pd}(1)-\mathrm{Cl}(1 \mathrm{~A})$ & $96.59(4)$ & $94.21(5)$ & $94.16(7)$ \\
$\mathrm{C}(1)-\mathrm{Pd}(1)-\mathrm{Cl}(1)$ & $94.98(5)$ & $99.92(7)$ & $100.50(8)$ \\
$\mathrm{Cl}(1)-\mathrm{Pd}(1)-\mathrm{Cl}(1 \mathrm{~A})$ & $87.31(2)$ & $84.88(2)$ & $83.79(3)$ \\
\hline
\end{tabular}


arrangement with respect to the $\mathrm{Pd}-\mathrm{Pd}$ axis, which is essentially similar to those of the cyclopalladated species with a five-member chelate ring [9]. A long distance between two palladium atoms $(3.457 \AA$ ) excludes the possibility of metal-metal bonding. The two diisopropylphenyl rings are nearly orthogonal with respect to the chelate ring.

The structures of both trans $-\mathbf{1}_{\mathbf{b}}$ and $c i s-\mathbf{1}_{\mathbf{b}}$ were determined by their X-ray diffraction. Single crystals of trans $-\mathbf{1}_{\mathbf{b}}$ were obtained by slow solvent evaporation from hexane at room temperature, but crystals of $c i s-\mathbf{1}_{\mathbf{b}}$ were grown from co-crystallization of trans- $\mathbf{1}_{\mathbf{b}}$ and $c i s-\mathbf{1}_{\mathbf{b}}$ from a solution of $\mathrm{CH}_{2} \mathrm{Cl}_{2}$ and water. The ORTEP plots of trans $-\mathbf{1}_{\mathbf{b}}$ and $c i s-\mathbf{1}_{\mathbf{b}}$ are illustrated in Figs. 3 and $\mathbf{4}$, with crystallographic information summarized in Table 5. Selected bond lengths and angles of trans $-\mathbf{1}_{\mathbf{b}}$ are collected in Table 3 as well. The structural feature around the $\mathrm{Pd}_{2} \mathrm{Cl}_{2}$ core of trans- $\mathbf{1}_{\mathbf{b}}$ is essentially similar to that of $\mathbf{1}_{\mathbf{a}}$. The geometry at palladium in trans $\mathbf{1}_{\mathbf{b}}$ is distorted square planar with the bite angle $(\mathrm{N}-\mathrm{Pd}-\mathrm{C})$ at the metal [80.91(9) $)^{\circ}$. The distances of $\mathrm{N}-\mathrm{C}(7)$ lie between 1.286(3) $\AA$, which is typical for $\mathrm{C}=\mathrm{N}$ bonds. The $\mathrm{C}, \mathrm{N}$ chelate

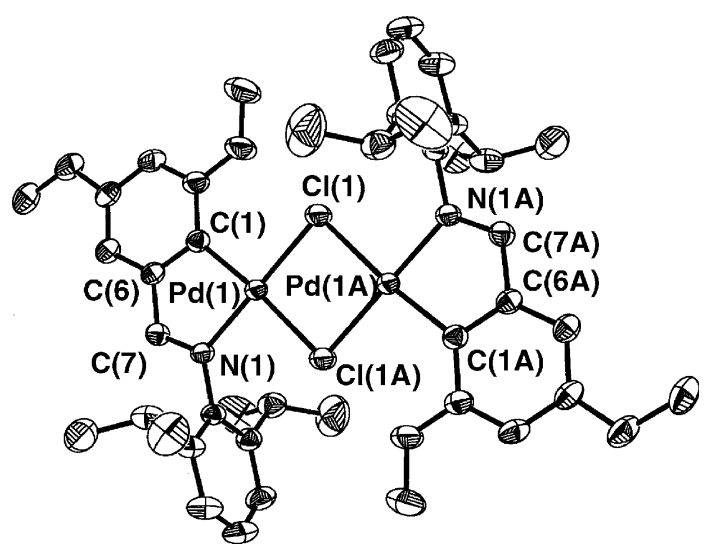

Fig. 3. Molecular structure of trans $-\mathbf{1}_{\mathbf{b}}$.

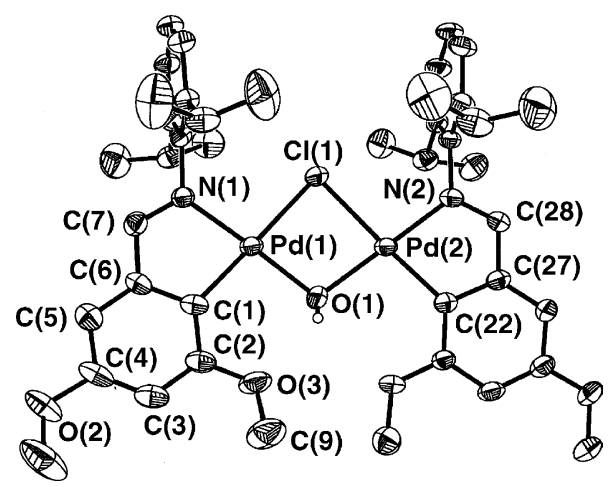

Fig. 4. ORTEP plot of cis-1 $\mathbf{b}$. $\mathrm{Pd}(1)-\mathrm{C}(1)$ 1.991(5) $\AA$, $\operatorname{Pd}(1)-\mathrm{N}(1)$ 2.011(4) $\AA, \operatorname{Pd}(1)-\mathrm{O}(1) 2.078(4) \AA, \mathrm{Pd}(1)-\mathrm{Cl}(1) 2.432(2) \AA, \mathrm{Pd}(2)-$ $\mathrm{C}(22)$ 1.991(5) $\mathrm{A}, \operatorname{Pd}(2)-\mathrm{N}(2) 2.019(4) \AA, \mathrm{Pd}(2)-\mathrm{O}(1) 2.062(4) \AA$, $\mathrm{Pd}(2)-\mathrm{Cl}(1) \quad 2.421(2) \quad \AA, \quad \mathrm{Pd} \cdots \mathrm{Pd} \quad 3.2798(6) \quad \AA, \quad \mathrm{C}(1)-\mathrm{Pd}(1)-\mathrm{N}(1)$ 80.6(2) ${ }^{\circ}, \mathrm{C}(1)-\mathrm{Pd}(1)-\mathrm{O}(1) 99.8(2)^{\circ}, \mathrm{N}(1)-\mathrm{Pd}(1)-\mathrm{O}(1) 177.7(2)^{\circ}, \mathrm{C}(22)-$ $\mathrm{Pd}(2)-\mathrm{Cl}(1) 178.7(2)^{\circ}, \mathrm{N}(2)-\mathrm{Pd}(2)-\mathrm{O}(1) 173.3(2)^{\circ}$. ring remains in planar geometry with the palladium metal center slightly off the plane. Similarly, crystal structure of $\mathbf{1}_{\mathbf{d}}$ (Fig. 5) was also determined. Selected bond distances and bond angles are summarized in Table 3. This structure is essentially comparable to those discussed in $\mathbf{1}_{\mathbf{a}}$ and trans $-\mathbf{1}_{\mathbf{b}}$, except the angle of $\mathrm{C}(1)$ $\operatorname{Pd}(1)-\mathrm{Cl}(1)\left[100.50(8)^{\circ}\right]$. This large deviation may be related to render the steric relief due to the isopropyl and aryl groups.

The X-ray diffraction analysis on $c i s-\mathbf{1}_{\mathbf{b}}$ shows a unique structure in which one of the bridging ligands is $\mathrm{OH}$ group. This observation is quite different from the other palladium dimmers. There are few dipalladium species with $\left[\mathrm{Pd}_{2} \mathrm{Cl}(\mathrm{OH})\right]$ core center appeared in the literature and only one crystal structure among them has been reported [10]. The relevant bond lengths and angles in cis-1 $\mathbf{1}_{\mathbf{b}}$ lie in the normal range and the coordination geometry is similar to trans- $\mathbf{1}_{\mathbf{b}}$; however, the conformation of the $\left[\mathrm{Pd}_{2} \mathrm{Cl}(\mathrm{OH})\right]$ core is different from that of $\left[\mathrm{Pd}_{2} \mathrm{Cl}_{2}\right]$. The dihedral angle for two planes defined by $\mathrm{Pd}(1)-\mathrm{O}(1)-\mathrm{Pd}(2)$ and $\mathrm{Pd}(1)-\mathrm{Cl}(1)-\mathrm{Pd}(2)$ is $22.8(2)^{\circ}$, clearly demonstrates a butterfly shape for the core of $\left[\mathrm{Pd}_{2} \mathrm{Cl}(\mathrm{OH})\right]$. The hydrogen of $\mathrm{OH}$ group is confirmed by both calculation and ${ }^{1} \mathrm{H}$ NMR shift $(\delta 2.81 \mathrm{ppm})$. The distances of $\mathrm{H}(1) \cdots \mathrm{O}(3)$ and $\mathrm{H}(1) \cdots \mathrm{O}(4)$ are 2.43(1) and 2.26(4) $\AA$, respectively, which are within the range of hydrogen bonds. Presumably, the cis-arrangement of ligands in this complex is stabilized through the hydrogen bonds of type $\mathrm{O}-\mathrm{H} \cdots \mathrm{O}-\mathrm{C}$, i.e. the methoxy groups on the aromatic ring might play the role on the construction of the hydroxy bridging ligand. This also explains why the other dipalladium complexes only exist in the core of $\left[\mathrm{Pd}_{2} \mathrm{Cl}_{2}\right]$. The Pd...Pd distance of cis- $\mathbf{1}_{\mathbf{b}}$ is 3.2798(6) $\AA$, indicating there is no metal-metal bond between them.

The signal at $1.97 \mathrm{ppm}$ on ${ }^{1} \mathrm{H}$ NMR corresponding to the methyl group of acetate reveals the coordination of that ligand to the metal center in the complexes $\mathbf{3}_{\mathrm{g}}$ and $\mathbf{3}_{\mathbf{h}}$. Nevertheless, the detail structural information of $\mathbf{3}_{\mathbf{g}}$ is obtained by its X-ray single-crystal analysis (Fig. 6). The diffraction study shows the acetato-bridged dipalladium

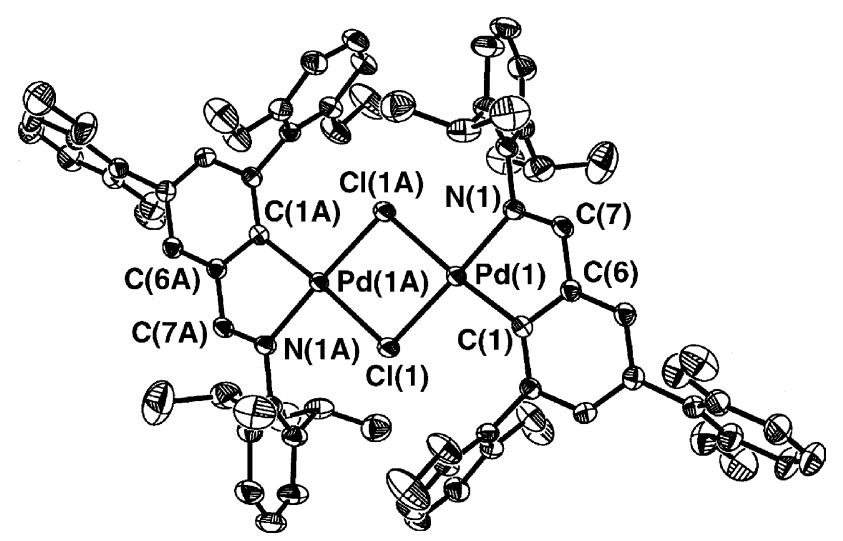

Fig. 5. ORTEP plot of $\mathbf{1}_{\mathbf{d}}$. 


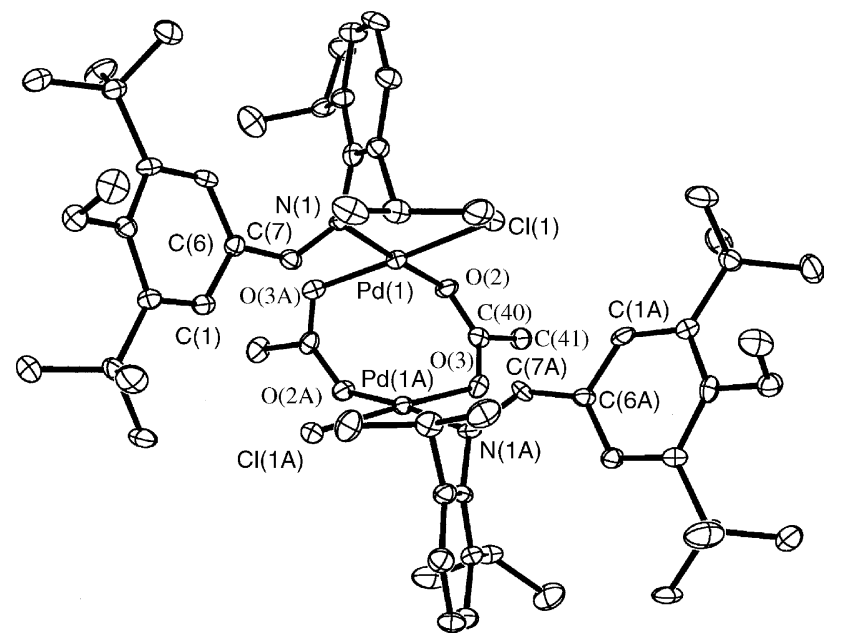

Fig. 6. Molecular structure of $\mathbf{3}_{\mathrm{g}} . \mathrm{Pd}(1)-\mathrm{N}(1) 2.010(6) \AA$ 的 $\mathrm{Pd}(1)-\mathrm{Cl}(1)$

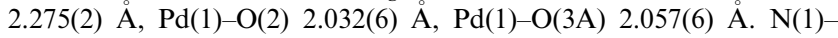
$\mathrm{Pd}(1)-\mathrm{Cl}(1) \quad 92.8(2)^{\circ}, \quad \mathrm{N}(1)-\mathrm{Pd}(1)-\mathrm{O}(3 \mathrm{~A}) \quad 88.7(2)^{\circ}, \quad \mathrm{O}(2)-\mathrm{Pd}(1)-\mathrm{Cl}(1)$ $88.7(2)^{\circ}, \mathrm{Pd} \cdots \mathrm{Pd} 3.009 \AA$ A.

core structure of the complex $\mathbf{3}_{\mathrm{g}}$. Both palladium metal centers appear to be slightly distorted square-planar defined by carbon ligand, the $\mathrm{N}$-imine atom and two oxygen atoms of acetate ligands. Like in the most instances, two bulky imine ligands are seated in the trans orientation. For the bond length of $\mathrm{Pd}(1)-\mathrm{N}(1)$ [2.010(6) $\AA$ ] is essentially similar to those of cyclopalladated species $\mathbf{1}_{\mathbf{a}}, \mathbf{1}_{\mathbf{b}}$ and $\mathbf{1}_{\mathbf{d}}$. The Pd...Pd distance of $\mathbf{3}_{\mathbf{g}}(3.009 \AA)$ appears to be shorter than those with chloro-bridged ones; however, there is no metal-metal interaction.
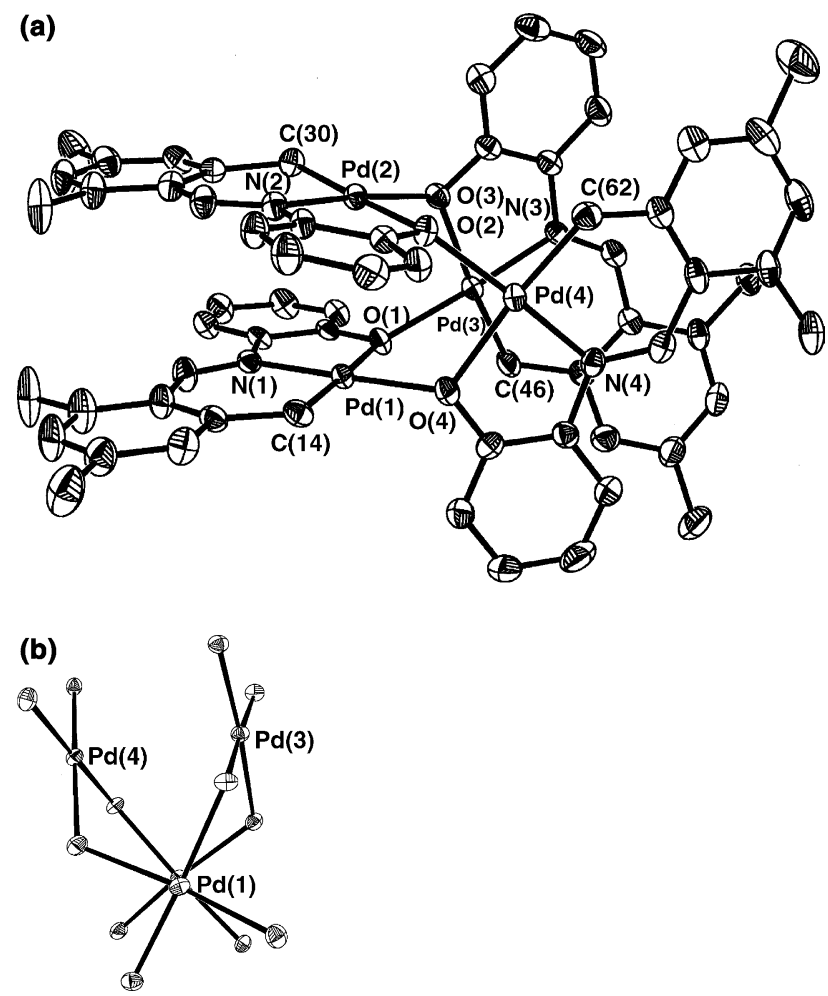

Fig. 7. (a) ORTEP plot of $7_{\mathbf{i}}$ (b) Conformation of $\left[\mathrm{Pd}_{4} \mathrm{O}_{4}\right]$ core.
Table 4

Bond distances $(\AA)$ and bond angles $\left(^{\circ}\right)$ of complex $\mathbf{7}_{\mathbf{i}}$

\begin{tabular}{lllr}
\hline $\mathrm{Pd}(1)-\mathrm{N}(1)$ & $1.965(4)$ & $\mathrm{N}(1)-\mathrm{Pd}(1)-\mathrm{C}(14)$ & $94.6(2)$ \\
$\mathrm{Pd}(2)-\mathrm{N}(2)$ & $1.969(4)$ & $\mathrm{N}(1)-\mathrm{Pd}(1)-\mathrm{O}(1)$ & $82.6(2)$ \\
$\mathrm{Pd}(3)-\mathrm{N}(3)$ & $1.984(4)$ & $\mathrm{N}(1)-\mathrm{Pd}(1)-\mathrm{O}(4)$ & $176.2(2)$ \\
$\mathrm{Pd}(4)-\mathrm{N}(4)$ & $1.977(4)$ & $\mathrm{O}(1)-\mathrm{Pd}(1)-\mathrm{O}(4)$ & $93.6(1)$ \\
$\mathrm{Pd}(1)-\mathrm{O}(1)$ & $2.130(3)$ & $\mathrm{N}(2)-\mathrm{Pd}(2)-\mathrm{C}(30)$ & $95.0(2)$ \\
$\mathrm{Pd}(2)-\mathrm{O}(2)$ & $2.117(3)$ & $\mathrm{N}(2)-\mathrm{Pd}(2)-\mathrm{O}(2)$ & $83.0(2)$ \\
$\mathrm{Pd}(3)-\mathrm{O}(3)$ & $2.120(3)$ & $\mathrm{N}(2)-\mathrm{Pd}(2)-\mathrm{O}(3)$ & $174.6(2)$ \\
$\mathrm{Pd}(4)-\mathrm{O}(4)$ & $2.123(3)$ & $\mathrm{O}(2)-\mathrm{Pd}(2)-\mathrm{O}(3)$ & $92.8(1)$ \\
$\mathrm{Pd}(1)-\mathrm{O}(4)$ & $2.060(3)$ & $\mathrm{N}(3)-\mathrm{Pd}(3)-\mathrm{C}(46)$ & $93.0(2)$ \\
$\mathrm{Pd}(2)-\mathrm{O}(3)$ & $2.045(3)$ & $\mathrm{N}(3)-\mathrm{Pd}(3)-\mathrm{O}(3)$ & $81.7(1)$ \\
$\mathrm{Pd}(3)-\mathrm{O}(1)$ & $2.066(3)$ & $\mathrm{N}(3)-\mathrm{Pd}(3)-\mathrm{O}(1)$ & $176.3(2)$ \\
$\mathrm{Pd}(4)-\mathrm{O}(2)$ & $2.067(3)$ & $\mathrm{O}(3)-\mathrm{Pd}(3)-\mathrm{O}(1)$ & $94.6(1)$ \\
$\mathrm{Pd}(1)-\mathrm{C}(14)$ & $1.988(5)$ & $\mathrm{N}(4)-\mathrm{Pd}(4)-\mathrm{C}(62)$ & $92.9(2)$ \\
$\mathrm{Pd}(2)-\mathrm{C}(30)$ & $1.992(5)$ & $\mathrm{N}(4)-\mathrm{Pd}(4)-\mathrm{O}(4)$ & $82.6(2)$ \\
$\operatorname{Pd}(3)-\mathrm{C}(46)$ & $1.992(5)$ & $\mathrm{N}(4)-\mathrm{Pd}(4)-\mathrm{O}(2)$ & $176.4(2)$ \\
$\operatorname{Pd}(4)-\mathrm{O}(62)$ & $1.973(5)$ & $\mathrm{O}(4)-\mathrm{Pd}(4)-\mathrm{O}(2)$ & $94.3(1)$ \\
\hline
\end{tabular}

For the crystals of the tetrameric palladium $7_{\mathbf{i}} \cdot 1 /$ $2 \mathrm{CH}_{2} \mathrm{Cl}_{2}$ crystallizes from a $\mathrm{CH}_{2} \mathrm{Cl}_{2}$ /hexane solution and in monoclinic space group $P 2_{1} / c$. Fig. 7(a) shows the ORTEP plot with thermal ellipsoid drawing at $50 \%$ probability level, revealing the presence of a tetranuclear neutral species. Selected bond distances and bond angles of $\mathbf{7}_{\mathbf{i}}$ are summarized in Table 4 . The slightly distorted square-planar environment of each Pd center is coordinated by the nitrogen, carbon as well as oxygen atoms from the same ligand, and one oxygen atom from the other unit. This tetramer consists of four $\left[\operatorname{Pd}\left(\mathbf{L}_{\mathbf{i}^{-}}-O, C, N\right)\right]$ palladium fragments linked by bridging oxygen atom to form a eight-membered ring of alternating $\mathrm{Pd}$ and $\mathrm{O}$ atoms [11]. This resulting $\left[\mathrm{Pd}_{4} \mathrm{O}_{4}\right]$ core has approximate $C_{2}$ symmetry [e.g. the $\mathrm{C}_{2}$ axis is perpendicular to and bisecting $\operatorname{Pd}(3)-\operatorname{Pd}(4)$ and $\operatorname{Pd}(1)-P d(2)]$ yielding a saddle conformation (Fig. 7(b)). The bond distances and bond angles are virtually the same for each fragment.

\section{Conclusion}

Through this study, it was determined that the substituents on the arylimine readily influence the structure of the cyclopalladated products. As expected, the cyclopalladation takes place preferentially at the position to form 5-endo or 6-endo metallocycle over other possibility. However, the bulky substituents in $\mathbf{L}_{\mathbf{g}}$ or $\mathbf{L}_{\mathbf{h}}$ hinder the occurrence of metallation. Furthermore, the contribution of hydrogen bond interaction between methoxy and hydroxy ligands in cis-1 $\mathbf{1}_{\mathbf{b}}$ allows the formation of mixed-donor bridged complexes $\left[\mathrm{Pd}_{2}(\mathrm{OH}) \mathrm{Cl}\right]$. On the other hand, the hydroxy group in $\mathbf{L}_{\mathbf{i}}$ provides the coordinating donor to form a tetrameric palladium species. Further coordination chemistry of these related complexes and their activity on catalysis are currently under investigation. 


\section{Experimental}

\subsection{General}

All reaction's, manipulation's and purification's steps were performed under a dry nitrogen atmosphere. Tetrahydrofuran was distilled under nitrogen from sodium benzophenone ketyl. Dichloromethane and acetonitrile were dried with $\mathrm{CaH}_{2}$ and distilled under nitrogen. Other chemicals and solvents were of analytical grade and were used as received unless otherwise stated.

Nuclear magnetic resonance spectra were recorded in $\mathrm{CDCl}_{3}$ on either a Bruker AM-300 or AVANCE-400 spectrometer. Chemical shifts are given in parts per million relative to $\mathrm{Me}_{4} \mathrm{~S}$ for ${ }^{1} \mathrm{H}$ and relative $85 \% \mathrm{H}_{3} \mathrm{PO}_{4}$ for ${ }^{31} \mathrm{P} \mathrm{NMR}$. Infrared spectra were measured on a Perkin-Elmer 983G spectrometer (Series-II) as $\mathrm{KBr}$ pallets, unless otherwise noted. Mass spectra were obtained from a Joel JMSD-300 instrument.

\subsection{Synthesis and characterization}

\subsubsection{General procedure for preparation of Schiff base} ligands $\left(\boldsymbol{L}_{\boldsymbol{a}-\boldsymbol{i}}\right)$

A methanol $(15 \mathrm{ml})$ solution of the substituted benzylaldehyde $(10 \mathrm{mmol})$ was added to the substituted aniline $(10 \mathrm{mmol})$ in a round-bottomed flask equipped with a condenser. The reaction mixture was stirred at reflux temperature for $24 \mathrm{~h}$. After the completion of reaction, the yellow crystal product was precipitated upon cooling. The solid product was filtered, washed with the pre-cold methanol and dried, whereas the liquid compounds $\mathbf{L}_{\mathbf{a}}$ and $\mathbf{L}_{\mathbf{h}}$ were purified by distillation off the starting aldehyde and chromatographied on aluminium oxide with elution of hexane. 3,5-Dimethoxybenzaldehyde was prepared according to the method reported [13].

\subsubsection{Benzylidene(2,6-diisopropylphenyl)amine $\left(\boldsymbol{L}_{\boldsymbol{a}}\right)$}

Light yellow liquid $(92 \%)$ : IR $(\mathrm{KBr}): 1646 \mathrm{~cm}^{-1}$ $\left(v_{\mathrm{C}=\mathrm{N}}\right) ;{ }^{1} \mathrm{H}$ NMR $\left(\mathrm{CDCl}_{3}, 400 \mathrm{MHz}\right): \delta 8.20(\mathrm{~s}, 1 \mathrm{H},-$ $H \mathrm{C}=\mathrm{N}), 7.93-7.88(\mathrm{~m}, 2 \mathrm{H}, \mathrm{Ar} H), 7.52-7.48(\mathrm{~m}, 3 \mathrm{H}, \mathrm{Ar}$ $H$ ), 7.18-7.09 (m, 3H, Ar $H$ ), 2.95 (sept., $J=9.2 \mathrm{~Hz}$, $2 \mathrm{H},-\mathrm{CH}), 1.16(\mathrm{~d}, J=9.2 \mathrm{~Hz}, 12 \mathrm{H},-M e) ;{ }^{13} \mathrm{C}$ NMR: $\delta$ $162.0,149.2,137.6,136.0,131.4,128.8,128.6,124.1$, 123.0, 27.9, 23.5. There spectra data are consistent with the reported ones [12].

\subsection{3. (3,5-Dimethoxybenzylidene) (2,6-diisopropylphenyl)- amine $\left(\boldsymbol{L}_{\boldsymbol{b}}\right)$}

Yellow solid (95\%): IR (KBr): $1604 \mathrm{~cm}^{-1}\left(v_{\mathrm{C}=\mathrm{N}}\right) ;{ }^{1} \mathrm{H}$ NMR $\left(\mathrm{CDCl}_{3}, 400 \mathrm{MHz}\right): \delta 8.11(\mathrm{~s}, 1 \mathrm{H},-H \mathrm{C}=\mathrm{N}), 7.17$ $(\mathrm{d}, J=6.7 \mathrm{~Hz}, 2 \mathrm{H}, \operatorname{Ar} H), 7.10(\mathrm{~d}, J=6.7 \mathrm{~Hz}, 1 \mathrm{H}, \mathrm{Ar}$ $H$ ), $7.07(\mathrm{~d}, J=2.3 \mathrm{~Hz}, 2 \mathrm{H}, \operatorname{Ar} H), 6.62(\mathrm{t}, J=2.3 \mathrm{~Hz}$, 1H, Ar H), 3.87 (s, 6H, -OMe); 2.97 (sept., $J=6.9 \mathrm{~Hz}$, $2 \mathrm{H},-\mathrm{CH}), 1.17(\mathrm{~d}, J=6.9 \mathrm{~Hz}, 12 \mathrm{H},-M e) ;{ }^{13} \mathrm{C}$ NMR: $\delta$
$161.9,161.1,149.0,138.0,137.6,124.2,123.0,106.2$, 104.0, 55.6, 27.9, 23.5; FAB $m / z$ : $325.1\left(\mathrm{M}^{+}\right)$. Anal. Calc. for $\mathrm{C}_{21} \mathrm{H}_{27} \mathrm{NO}_{2}$ : C, 77.50; H, 8.36; N, 4.30. Found: C, 77.53; H, 8.47; N, 4.30\%.

\subsection{4. (3,5-Difluorobenzylidene)(2,6-diisopropylphenyl)} amine $\left(\boldsymbol{L}_{c}\right)$

Yellow solid (95\%): IR $(\mathrm{KBr}): 1595 \mathrm{~cm}^{-1}\left(v_{\mathrm{C}=\mathrm{N}}\right) ;{ }^{1} \mathrm{H}$ $\operatorname{NMR}\left(\mathrm{CDCl}_{3}, 400 \mathrm{MHz}\right): \delta 8.11(\mathrm{~s}, 1 \mathrm{H},-H \mathrm{C}=\mathrm{N}), 7.42$ $\left(\mathrm{d}, J_{\mathrm{HF}}=5.8 \mathrm{~Hz}, 2 \mathrm{H}, \operatorname{Ar} H\right), 7.16-7.08(\mathrm{~m}, 3 \mathrm{H}, \operatorname{Ar} H)$, $6.94\left(\mathrm{t}, J_{\mathrm{HF}}=8.6 \mathrm{~Hz}, 1 \mathrm{H}, \operatorname{Ar} H\right), 2.89$ (sept., $J=6.8 \mathrm{~Hz}$, $2 \mathrm{H},-\mathrm{CH}), 1.15(\mathrm{~d}, J=6.8 \mathrm{~Hz}, 12 \mathrm{H},-\mathrm{Me}) ;{ }^{13} \mathrm{C} \mathrm{NMR}: \delta$ $163.3\left(\mathrm{dd}, J_{\mathrm{CF}}=248.3 \mathrm{~Hz}, 12.5 \mathrm{~Hz}\right), 159.6,148.4,139.2$, $137.3,124.6,123.1,111.2\left(\mathrm{dd}, J_{\mathrm{CF}}=18.6 \mathrm{~Hz}, 7.0 \mathrm{~Hz}\right)$, $106.6\left(\mathrm{t}, J_{\mathrm{CF}}=25.4 \mathrm{~Hz}\right), 28.0$, 23.4; EI $m / z: 301.1\left(\mathrm{M}^{+}\right)$. Anal. Calc. for $\mathrm{C}_{19} \mathrm{H}_{21} \mathrm{~F}_{2} \mathrm{~N} \mathrm{C}, 75.72 ; \mathrm{H}, 7.02 ; \mathrm{N}, 4.65$. Found: C, 75.67; H, 6.97; N, 4.44\%.

\subsection{5. [3,5-bis (2',6'- dimethoxyphenyl) benzylidene](2,6- Diisopropylphenyl)amine $\left(\boldsymbol{L}_{\boldsymbol{d}}\right)$}

White solid $(85 \%)$, IR $(\mathrm{KBr}): 1635 \mathrm{~cm}^{-1}\left(v_{\mathrm{C}=\mathrm{N}}\right) ;{ }^{1} \mathrm{H}$ NMR $\left(\mathrm{CDCl}_{3}, 400 \mathrm{MHz}\right): \delta 8.23(\mathrm{~s}, 1 \mathrm{H},-H \mathrm{C}=\mathrm{N}), 7.88$ $(\mathrm{d}, J=1.2 \mathrm{~Hz}, 2 \mathrm{H}, \operatorname{Ar} H), 7.58(\mathrm{t}, J=1.2 \mathrm{~Hz}, 1 \mathrm{H}, \mathrm{Ar}$ $H$ ), $7.28(\mathrm{t}, J=8.4 \mathrm{~Hz}, 2 \mathrm{H}, \mathrm{Ar} H), 7.15-7.09$ (m, 3H, Ar $H), 6.66(\mathrm{~d}, J=8.4 \mathrm{~Hz}, 4 \mathrm{H}, \mathrm{Ar} H), 3.77$ (s, $12 \mathrm{H},-O M e)$, 3.06 (sept, $J=6.8 \mathrm{~Hz}, 2 \mathrm{H},-\mathrm{CH}), 1.16(\mathrm{~d}, J=6.8 \mathrm{~Hz}$, $12 \mathrm{H},-M e) ;{ }^{13} \mathrm{C}$ NMR: $\delta 162.5,157.7,149.6,137.7$, $137.3,134.7,133.3,130.2,128.7,123.7,122.9,118.8$, 104.1, 55.9, 27.7, 23.5; FAB $m / z$ : $537.3\left(\mathrm{M}^{+}\right)$. Anal. Calc. for $\mathrm{C}_{35} \mathrm{H}_{39} \mathrm{NO}_{4}$ : C, 78.18; H, 7.31; N, 2.61. Found: C, $78.11 ; \mathrm{H}, 7.02 ; \mathrm{N}, 2.35 \%$.

\subsection{6. (4-Chlorobenzylidene) (2,6-diisopropylphenyl) amine $\left(\boldsymbol{L}_{e}\right)$}

Yellow solid (92\%); IR (KBr): $1640 \mathrm{~cm}^{-1}\left(v_{\mathrm{C}=\mathrm{N}}\right) ;{ }^{1} \mathrm{H}$ $\operatorname{NMR}\left(\mathrm{CDCl}_{3}, 400 \mathrm{MHz}\right): \delta 8.14(\mathrm{~s}, 1 \mathrm{H},-H \mathrm{C}=\mathrm{N}), 7.83$ $(\mathrm{d}, J=8.2 \mathrm{~Hz}, 2 \mathrm{H}, \mathrm{Ar} H), 7.46(\mathrm{~d}, J=8.2 \mathrm{~Hz}, 2 \mathrm{H}, \mathrm{Ar}$ $H$ ), 7.15-7.07 (m, 3H, Ar $H$ ), 2.92 (sept., $J=6.9 \mathrm{~Hz}$, $2 \mathrm{H},-\mathrm{CH}), 1.15(\mathrm{~d}, J=6.9 \mathrm{~Hz}, 12 \mathrm{H},-M e) ;{ }^{13} \mathrm{C}$ NMR: $\delta$ 160.6, 148.9, 137.5, 137.4, 134.4, 129.7, 129.1, 124.3, 123.0, 27.9, 23.4; FAB $m / z: 299.1\left(\mathrm{M}^{+}\right)$. Anal. Calc. for $\mathrm{C}_{19} \mathrm{H}_{22} \mathrm{ClN}$ : C, 76.11; H, 7.40; N, 4.67. Found: C, 76.22; $\mathrm{H}, 7.41 ; \mathrm{N}, 4.70 \%$.

\subsection{7. (2-Bromobenzylidene)(2,6-diispropylphenyl)amine $\left(\boldsymbol{L}_{f}\right)$}

Yellow solid (90\%); IR (KBr): $1632 \mathrm{~cm}^{-1}\left(v_{\mathrm{C}=\mathrm{N}}\right) ;{ }^{1} \mathrm{H}$ $\mathrm{NMR}\left(\mathrm{CDCl}_{3}, 400 \mathrm{MHz}\right): \delta 8.56(\mathrm{~s}, 1 \mathrm{H},-H \mathrm{C}=\mathrm{N}), 8.25$ $(\mathrm{d}, J=8.0 \mathrm{~Hz}, 1 \mathrm{H}, \operatorname{Ar} H), 7.62(\mathrm{~d}, J=8.0 \mathrm{~Hz}, 1 \mathrm{H}, \mathrm{Ar}$ $H), 7.44(\mathrm{t}, J=8.0 \mathrm{~Hz}, 1 \mathrm{H}, \operatorname{Ar} H), 7.35(\mathrm{t}, J=8.0 \mathrm{~Hz}$, 1H, Ar $H$ ), 7.18-7.11 (m, 3H, Ar H), 2.96 (sept., $J=6.9$ $\mathrm{Hz}, 2 \mathrm{H},-\mathrm{CH}), 1.19$ (d, $J=6.9 \mathrm{~Hz}, 12 \mathrm{H},-\mathrm{Me}) ;{ }^{13} \mathrm{C}$ NMR: $\delta 161.4,148.9,137.5,134.5,133.2,132.4,128.8$, 127.8, 125.7, 124.4, 123.1, 27.9, 23.5; FAB $m / z: 343.1$ $\left(\mathrm{M}^{+}\right)$. Anal. Calc. for $\mathrm{C}_{19}-\mathrm{H}_{22} \mathrm{BrN}$ : C, 66.28; H, 6.44; N, 4.07. Found: C, 66.23; H, 6.52; N, 4.29\%. 
4.2.8. (3,5-Di-tert-butyl-4-methoxybenzylidene)(2,6-diisopropylphenyl) amine $\left(\boldsymbol{L}_{g}\right)$

Yellow solid (92\%): m.p.: $113-114{ }^{\circ} \mathrm{C}$; IR (KBr): 1645 $\mathrm{cm}^{-1}\left(v_{\mathrm{C}=\mathrm{N}}\right) ;{ }^{1} \mathrm{H}$ NMR $\left(\mathrm{CDCl}_{3}, 400 \mathrm{MHz}\right): \delta 8.09(\mathrm{~s}$, $1 \mathrm{H},-H \mathrm{C}=\mathrm{N}), 7.79(\mathrm{~s}, 2 \mathrm{H}, \operatorname{Ar} H), 7.15-7.09(\mathrm{~m}, 3 \mathrm{H}$, Ar $H$ ), 3.76 (s, 3H, $-\mathrm{OMe}$ ), 2.99 (sept, $J=6.8 \mathrm{~Hz}, 2 \mathrm{H}$, $-\mathrm{CH}), 1.48(\mathrm{~s}, 18 \mathrm{H},-\mathrm{Me}), 1.17(\mathrm{~d}, J=6.8 \mathrm{~Hz}, 12 \mathrm{H}$, $-M e) ;{ }^{13} \mathrm{C}$ NMR: $\delta 162.7,161.9,149.4,144.5,137.8$, 130.6, 127.2, 123.9, 122.9, 64.4, 35.9, 32.0, 27.9, 23.5; FAB $m / z: 407.3\left(\mathrm{M}^{+}\right)$. Anal. Calc. for $\mathrm{C}_{28} \mathrm{H}_{41} \mathrm{NO}$ : C, 82.50; H, 10.14; N, 3.44. Found: C, 82.63; H, 10.38; N, $3.16 \%$.

4.2.9. (3,5-Di-tert-butyl-4-methoxybenzylidene) (2,6-dimethylphenyl) amine $\left(\boldsymbol{L}_{\boldsymbol{h}}\right)$

Orange liquid (85\%); IR (KBr): $1646 \mathrm{~cm}^{-1}\left(v_{\mathrm{C}=\mathrm{N}}\right) ;{ }^{1} \mathrm{H}$ NMR $\left(\mathrm{CDCl}_{3}, 300 \mathrm{MHz}\right): \delta 8.20(\mathrm{~s}, 1 \mathrm{H},-H \mathrm{C}=\mathrm{N}), 7.88$ (s, 2H, Ar H), $7.12(\mathrm{~d}, J=7.6 \mathrm{~Hz}, 2 \mathrm{H}, \operatorname{Ar} H), 7.00(\mathrm{~d}$, $J=7.6 \mathrm{~Hz}, 1 \mathrm{H}, \mathrm{Ar} H), 3.81(\mathrm{~s}, 3 \mathrm{H},-\mathrm{O} M e), 2.22(\mathrm{~s}, 6 \mathrm{H}$, $-\mathrm{Me}), 1.55$ (s, $18 \mathrm{H},-\mathrm{Me}),{ }^{13} \mathrm{C}$ NMR: $\delta 162.8,162.7$, 151.5, 144.5, 130.7, 128.0, 127.3, 127.1, 123.5, 64.5, 36.0, 32.1, 18.5; FAB $m / z$ : $351.3\left(\mathrm{M}^{+}\right)$. Anal. Calc. for $\mathrm{C}_{28} \mathrm{H}_{41} \mathrm{NO}$ : C, 82.50; H, 7.31; N, 2.61. Found: C, 82.12; $\mathrm{H}, 6.97$; N, 2.27\%.

4.2.10. (2,4,6-Trimethylbenzylidene) (2,6-dihydroxyphenyl) amine $\left(\boldsymbol{L}_{\boldsymbol{i}}\right)$

Pale brown solid (82\%); IR (KBr): $1630 \mathrm{~cm}^{-1}\left(v_{\mathrm{C}=\mathrm{N}}\right)$; ${ }^{1} \mathrm{H}$ NMR $\left(\mathrm{CDCl}_{3}, 400 \mathrm{MHz}\right): \delta 9.10(\mathrm{~s}, 1 \mathrm{H},-\mathrm{HC}=\mathrm{N})$, $7.28(\mathrm{~d}, J=6.6 \mathrm{~Hz}, 1 \mathrm{H}$, Ar $H), 7.21(\mathrm{t}, J=8.0 \mathrm{~Hz}, 1 \mathrm{H}$, Ar $H), 7.04(\mathrm{~d}, J=8.0 \mathrm{~Hz}, 1 \mathrm{H}, \operatorname{Ar} H), 6.97(\mathrm{~s}, 2 \mathrm{H}, \mathrm{Ar}$ $H), 6.94(\mathrm{t}, J=6.8 \mathrm{~Hz}, 2 \mathrm{H}$, Ar $H), 2.59(\mathrm{~s}, 6 \mathrm{H},-M e)$, $2.35(\mathrm{~s}, 3 \mathrm{H},-\mathrm{Me}) ;{ }^{13} \mathrm{C}$ NMR: $\delta$ 157.7, 152.0, 140.4, $138,9,136.8,130.1,129.9,128.4,120.0,115.4,114.8$, 21.5, 21.2; FAB $m / z: 240.2\left(\mathrm{M}^{+}+1\right)$. Anal. Calc. for $\mathrm{C}_{16} \mathrm{H}_{17} \mathrm{NO}: \mathrm{C}, 80.30 ; \mathrm{H}, 7.16$; N, 5.85. Found: C, 80.15; $\mathrm{H}, 7.26 ; \mathrm{N}, 5.50 \%$.

\subsection{Generanl procedure for preparation of palladacycle complexes $\boldsymbol{1}_{\boldsymbol{a}-f}$}

To a round-bottomed flask with a stir bar was placed with palladium dichloride $(118 \mathrm{mg}, 0.67 \mathrm{mmol})$ under the nitrogen. Pre-dried acetonitrile $(10 \mathrm{ml})$ was added and the resulting mixture was stirred at room temperature. The mixture turned into yellow color immediately. After stirring for two days, the solvent was removed to dryness. Then ligand $(0.71 \mathrm{mmol})$, excess of sodium acetate $(110 \mathrm{mg}, 10.4 \mathrm{mmol})$ and tetrahydrofuran $(15 \mathrm{ml})$ were added. The reaction mixture was stirred at room temperature for another $38 \mathrm{~h}$. After removal of solvents, dichloromethane $(20 \mathrm{ml})$ was added and the solution was filtered through cilite. The filtrate was concentrated and the residue was washed with hexane $(10 \mathrm{ml} \times 3)$ to give the desired product.

\subsubsection{Complex $\boldsymbol{1}_{\boldsymbol{a}}$}

Yellow solid (75\%): IR $(\mathrm{KBr}): 1603 \mathrm{~cm}^{-1}\left(v_{\mathrm{C}=\mathrm{N}}\right) ;{ }^{1} \mathrm{H}$ NMR $\left(\mathrm{CDCl}_{3}, 400 \mathrm{MHz}\right): \delta 7.72(\mathrm{~s}, 1 \mathrm{H},-\mathrm{HC}=\mathrm{N})$, 7.35-6.95 (m, 7H, Ar H), 3.55-3.45 (m, 2H, -CH), 1.36 $(\mathrm{d}, J=6.4 \mathrm{~Hz}, 6 \mathrm{H},-\mathrm{Me}), 1.12(\mathrm{~d}, J=6.6 \mathrm{~Hz}, 6 \mathrm{H},-$ Me); ${ }^{13} \mathrm{C}$ NMR: $\delta$ 176.2, 155.4, 145.7, 144.3, 141.5, 133.9, 130.9, 127.9, 127.7, 124.7, 123.2, 28.2, 24.4, 23.0; FAB $m / z: \quad 777.1 \quad\left(\mathrm{M}^{+}-\mathrm{Cl}^{-}\right)$. Anal. Calc. for $\mathrm{C}_{38} \mathrm{H}_{44} \mathrm{Cl}_{2} \mathrm{~N}_{2} \mathrm{Pd}_{2}$ : C, 56.17; $\mathrm{H}, 5.46 ; \mathrm{N}, 3.45$. Found: $\mathrm{C}$, $56.09 ; \mathrm{H}, 5.49 ; \mathrm{N}, 3.40 \%$.

\subsubsection{Complex trans- $\boldsymbol{1}_{\boldsymbol{b}}$}

Yellow solid; IR (KBr): $1584 \mathrm{~cm}^{-1}\left(v_{\mathrm{C}=\mathrm{N}}\right) ;{ }^{1} \mathrm{H}$ NMR $\left(\mathrm{CDCl}_{3}, 400 \mathrm{MHz}\right): \delta 7.66(\mathrm{~s}, 1 \mathrm{H},-\mathrm{HC}=\mathrm{N}), 7.63(\mathrm{~s}, 1 \mathrm{H}$, $-\mathrm{HC}=\mathrm{N}), 7.22(\mathrm{t}, J=7.5 \mathrm{~Hz}, 1 \mathrm{H}, \operatorname{Ar} \mathrm{H}), 7.11(\mathrm{~d}$, $J=7.5 \mathrm{~Hz}, 2 \mathrm{H}, \operatorname{Ar} \mathrm{H}), 7.08(\mathrm{t}, J=7.6 \mathrm{~Hz}, 1 \mathrm{H}, \operatorname{Ar} \mathrm{H})$, $6.92(\mathrm{~d}, J=7.6 \mathrm{~Hz}, 2 \mathrm{H}, \operatorname{Ar} \mathrm{H}), 6.53(\mathrm{~s}, 1 \mathrm{H}, \mathrm{Ar} \mathrm{H}), 6.52$ (s, 1H, Ar H), 6.30 (s, 1H, Ar H), 6.19 (s, 1H, Ar H), 3.79 (s, 3H, -OMe), 3.76 (s, 3H, -OMe), 3.74 (s, 3H, OMe), 3.55-3.45 (m, 2H, -CH), 3.41 (s, 3H, -OMe), 3.34-3.24 (m, 2H, $-\mathrm{CH}), 1.39$ (d, $J=6.7 \mathrm{~Hz}, 6 \mathrm{H},-\mathrm{Me})$, $1.14(\mathrm{~d}, J=6.7 \mathrm{~Hz}, 6 \mathrm{H},-\mathrm{Me}), 1.10(\mathrm{~d}, J=6.7 \mathrm{~Hz}, 6 \mathrm{H}$, $-\mathrm{Me}), 1.01(\mathrm{~d}, J=6.7 \mathrm{~Hz}, 6 \mathrm{H},-\mathrm{Me}) ;{ }^{13} \mathrm{C} \mathrm{NMR}\left(\mathrm{CDCl}_{3}\right.$, $100 \mathrm{MHz}): \delta 177.2,177.0,165.0,164.7,158.4,146.7$, $144.3,142.7,141.7,141.6,132.8,132.4,127.4,127.3$, 123.0, 122.6, 104.8, 104.7, 104.1, 103.4, 55.9, 55.4, 28.2, 28.0, 24.6, 24.5, 22.8, 22.7; FAB $m / z$ : $932.1\left(\mathrm{M}^{+}\right), 897.1$ $\left(\mathrm{M}^{+}-\mathrm{Cl}^{-}\right)$. Anal. Calc. for $\mathrm{C}_{42} \mathrm{H}_{52} \mathrm{Cl}_{2} \mathrm{~N}_{2} \mathrm{O}_{4} \mathrm{Pd}_{2}$. $2 \mathrm{C}_{4} \mathrm{H}_{8} \mathrm{O}: \mathrm{C}, 55.77 ; \mathrm{H}, 6.36 ; \mathrm{N}, 2.60$. Found: $\mathrm{C}, 55.58 ; \mathrm{H}$, $6.17 ; \mathrm{N}, 2.38 \%$.

\subsubsection{Complex cis- $\boldsymbol{1}_{\boldsymbol{b}}$}

IR (KBr): $1586 \mathrm{~cm}^{-1}\left(v_{\mathrm{C}=\mathrm{N}}\right) ;{ }^{1} \mathrm{H}$ NMR $\left(\mathrm{CDCl}_{3}, 400\right.$ $\mathrm{MHz}): \delta 7.56(\mathrm{~s}, 1 \mathrm{H},-\mathrm{HC}=\mathrm{N}), 7.12(\mathrm{t}, J=7.5 \mathrm{~Hz}, 1 \mathrm{H}$, $\operatorname{Ar~H}), 6.99$ (d, $J=7.5 \mathrm{~Hz}, 2 \mathrm{H}, \operatorname{Ar~H}), 6.58(\mathrm{~d}, J=2.4$ $\mathrm{Hz}, 1 \mathrm{H}, \operatorname{Ar} \mathrm{H}), 6.38(\mathrm{~d}, J=2.4 \mathrm{~Hz}, 1 \mathrm{H}, \operatorname{Ar~H}), 3.84(\mathrm{~s}$, $3 \mathrm{H},-\mathrm{OMe}$ ), 3.78 (s, $3 \mathrm{H},-\mathrm{OMe}$ ), 3.35 (sept., $J=6.8 \mathrm{~Hz}$, $2 \mathrm{H},-\mathrm{CH}), 2.81(\mathrm{~s}, 1 \mathrm{H}, \mathrm{OH}) 1.21(\mathrm{~d}, J=6.8 \mathrm{~Hz}, 6 \mathrm{H},-$ $\mathrm{Me}), 1.02(\mathrm{~d}, J=6.8 \mathrm{~Hz}, 6 \mathrm{H},-\mathrm{Me}) ;{ }^{13} \mathrm{C} \mathrm{NMR}\left(\mathrm{CDCl}_{3}\right.$, $100 \mathrm{MHz}): \delta$ 176.0, 165.8, 158.1, 146.5, 143.8, 141.4, 131.6, 127.3, 123.0, 104.9, 104.0, 57.2, 55.5, 27.9, 24.4, 23.0. Due to the co-crystallization with trans $-\mathbf{1}_{\mathbf{b}}$, elemental analysis of this compound cannot be obtained.

\subsubsection{Complex $\boldsymbol{1}_{\boldsymbol{c}}$}

Yellow solid (65\%): IR (KBr): $1570 \mathrm{~cm}^{-1}\left(v_{\mathrm{C}=\mathrm{N}}\right) ;{ }^{1} \mathrm{H}$ $\operatorname{NMR}\left(\mathrm{CDCl}_{3}, 400 \mathrm{MHz}\right): \delta 7.70(\mathrm{~s}, 1 \mathrm{H},-\mathrm{HC}=\mathrm{N}), 7.67$ $(\mathrm{s}, 1 \mathrm{H},-\mathrm{HC}=\mathrm{N}), 7.29(\mathrm{t}, J=7.7 \mathrm{~Hz}, 1 \mathrm{H}, \operatorname{Ar} \mathrm{H}), 7.15(\mathrm{~d}$, $J=7.7 \mathrm{~Hz}, 2 \mathrm{H}, \operatorname{Ar~H}), 7.12(\mathrm{t}, J=7.7 \mathrm{~Hz}, 1 \mathrm{H}, \operatorname{Ar} \mathrm{H})$, $6.95(\mathrm{~d}, J=7.7 \mathrm{~Hz}, 2 \mathrm{H}, \operatorname{Ar} \mathrm{H}), 6.91\left(\mathrm{~d}, J_{\mathrm{H}-\mathrm{F}}=7.0 \mathrm{~Hz}\right.$, $2 \mathrm{H}, \mathrm{Ar} \mathrm{H}), 6.64\left(\mathrm{dd}, J_{\mathrm{H}-\mathrm{F}}=7.9 \mathrm{~Hz}, J_{\mathrm{H}-\mathrm{F}}=7.9 \mathrm{~Hz}, 1 \mathrm{H}\right.$, Ar H), 6.53(dd, $J_{\mathrm{H}-\mathrm{F}}=7.9 \mathrm{~Hz}, J_{\mathrm{H}-\mathrm{F}}=7.9 \mathrm{~Hz}, 1 \mathrm{H}, \mathrm{Ar}$ $\mathrm{H}$ ), 3.40 (sept., $J=6.7 \mathrm{~Hz}, 2 \mathrm{H},-\mathrm{CH}$ ), 3.20 (sept., $J=6.7 \mathrm{~Hz}, 2 \mathrm{H},-\mathrm{CH}), 1.41(\mathrm{~d}, J=6.7 \mathrm{~Hz}, 6 \mathrm{H},-\mathrm{Me})$, $1.17(\mathrm{~d}, J=6.7 \mathrm{~Hz}, 6 \mathrm{H},-\mathrm{Me}), 1.13(\mathrm{~d}, J=6.7 \mathrm{~Hz}, 6 \mathrm{H}$, $-\mathrm{Me}), 1.04(\mathrm{~d}, J=6.7 \mathrm{~Hz}, 6 \mathrm{H},-\mathrm{Me}) ;{ }^{13} \mathrm{C} \mathrm{NMR}\left(\mathrm{CDCl}_{3}\right.$, 
$100 \mathrm{MHz}): \delta 176.6,176.4,167.3\left(\mathrm{~d}, J_{\mathrm{C}-\mathrm{F}}=247 \mathrm{~Hz}\right)$, $167.2\left(\mathrm{~d}, J_{\mathrm{C}-\mathrm{F}}=247 \mathrm{~Hz}\right), 160.8\left(\mathrm{~d}, J_{\mathrm{C}-\mathrm{F}}=244 \mathrm{~Hz}\right)$, $160.7\left(\mathrm{~d}, J_{\mathrm{C}-\mathrm{F}}=244 \mathrm{~Hz}\right), 147.5\left(\mathrm{~d}, J_{\mathrm{C}-\mathrm{F}}=16 \mathrm{~Hz}\right), 147.4$ $\left(\mathrm{d}, J_{\mathrm{C}-\mathrm{F}}=16 \mathrm{~Hz}\right), 143.8,142.2,141.3,141.2,130.2(\mathrm{~d}$, $\left.J_{\mathrm{C}-\mathrm{F}}=36 \mathrm{~Hz}\right), 130.1\left(\mathrm{~d}, J_{\mathrm{C}-\mathrm{F}}=36 \mathrm{~Hz}\right), 128.3,127.9$, $123.4,122.9,111.0\left(\mathrm{~d}, J_{\mathrm{C}-\mathrm{F}}=22 \mathrm{~Hz}\right), 110.9\left(\mathrm{~d}, J_{\mathrm{C}-\mathrm{F}}=22\right.$ $\mathrm{Hz}), 108.1\left(\mathrm{~d}, J_{\mathrm{C}-\mathrm{F}}=32 \mathrm{~Hz}\right), 107.8\left(\mathrm{~d}, J_{\mathrm{C}-\mathrm{F}}=32 \mathrm{~Hz}\right)$, 28.4, 28.2, 24.5, 22.7, 22.6; FAB $m / z: 849.0\left(\mathrm{M}^{+}-\mathrm{Cl}^{-}\right)$. Anal. Calc. for $\mathrm{C}_{38} \mathrm{H}_{40} \mathrm{Cl}_{2} \mathrm{~F}_{4} \mathrm{~N}_{2} \mathrm{Pd}_{2}$ : C, 51.50; $\mathrm{H}, 4.56$; $\mathrm{N}, 3.17$. Found: C, 51.38; H, 4.58; N, 3.11\%.

\subsubsection{Complex $\boldsymbol{1}_{\boldsymbol{d}}$}

Yellow solid (56\%); IR (KBr): $1591 \mathrm{~cm}^{-1}\left(v_{\mathrm{C}=\mathrm{N}}\right) ;{ }^{1} \mathrm{H}$ $\mathrm{NMR}\left(\mathrm{CDCl}_{3}, 400 \mathrm{MHz}\right): \delta 7.61(\mathrm{~s}, 1 \mathrm{H},-\mathrm{HC}=\mathrm{N}), 7.28$ $(\mathrm{t}, J=7.7 \mathrm{~Hz}, 1 \mathrm{H}, \operatorname{Ar} \mathrm{H}), 7.20(\mathrm{~d}, J=2.1 \mathrm{~Hz}, 1 \mathrm{H}, \mathrm{Ar}$ $\mathrm{H}), 7.16(\mathrm{t}, J=8.3 \mathrm{~Hz}, 1 \mathrm{H}, \operatorname{Ar~H}), 7.08(\mathrm{~d}, J=7.7 \mathrm{~Hz}$, $2 \mathrm{H}, \operatorname{Ar} \mathrm{H}), 6.82(\mathrm{~d}, J=2.1 \mathrm{~Hz}, 1 \mathrm{H}, \operatorname{Ar} \mathrm{H}), 6.77(\mathrm{t}$, $J=8.3 \mathrm{~Hz}, 1 \mathrm{H}, \operatorname{Ar~H}), 6.55(\mathrm{~d}, J=8.3 \mathrm{~Hz}, 2 \mathrm{H}, \operatorname{Ar} \mathrm{H})$, $6.18(\mathrm{~d}, J=8.3 \mathrm{~Hz}, 2 \mathrm{H}, \mathrm{Ar} \mathrm{H}), 3.71$ (s, 6H, -OMe), 3.67 (s, $6 \mathrm{H},-\mathrm{OMe}$ ), 3.42 (sept., $J=6.8 \mathrm{~Hz}, 2 \mathrm{H},-\mathrm{CH}$ ), 1.32 $(\mathrm{d}, J=6.8 \mathrm{~Hz}, 6 \mathrm{H},-\mathrm{Me}), 1.11(\mathrm{~d}, J=6.8 \mathrm{~Hz}, 6 \mathrm{H},-$ $\mathrm{Me}) ;{ }^{13} \mathrm{C}$ NMR: $\delta 176.9,157.6,157.5,153.8,145.5$, $144.3,141.5,139.3,138.0,129.5,129.0,128.3,128.2$, $127.2,123.1,122.5,118.2,105.1,104.2,56.3,55.8,27.8$, 24.6, 23.3; $\quad$ FAB $m / z: \quad 1355.3 \quad\left(\mathrm{M}^{+}+1\right)$; $\mathrm{C}_{70} \mathrm{H}_{76} \mathrm{Cl}_{2} \mathrm{~N}_{2} \mathrm{O}_{8} \mathrm{Pd}_{2}: \mathrm{C}, 61.95 ; \mathrm{H}, 5.64 ; \mathrm{N}, 2.06$. Found: C, 61.81; H, 5.55; N, 2.04\%.

\subsubsection{Complex $\boldsymbol{1}_{e}$}

Yellow solids (75\%): IR (KBr): $1602 \mathrm{~cm}^{-1}\left(v_{\mathrm{C}=\mathrm{N}}\right) ;{ }^{1} \mathrm{H}$ NMR $\left(\mathrm{CDCl}_{3}, 400 \mathrm{MHz}\right): \delta 7.70(\mathrm{~s}, 1 \mathrm{H},-\mathrm{HC}=\mathrm{N}), 7.32$ (brs, 1H, Ar H), 7.20-6.95 (m, 5H, Ar H), 3.43 (brs, 2H, $-\mathrm{CH}), 1.36$ (br, 6H, $-\mathrm{Me}$ ), $1.12(\mathrm{~d}, J=6.4 \mathrm{~Hz}, 6 \mathrm{H}$, -Me); ${ }^{13} \mathrm{C}$ NMR: $\delta$ 175.4, 156.0, 144.0, 143.8, 141.3, 136.7, 133.4, 128.6, 128.2, 125.2, 123.4, 28.3, 24.4, 22.9; FAB $m / z: \quad 844.1 \quad\left(\mathrm{M}^{+}-\mathrm{Cl}^{-}\right)$. Anal. Calc. for $\mathrm{C}_{38} \mathrm{H}_{42} \mathrm{Cl}_{4} \mathrm{~N}_{2} \mathrm{Pd}_{2}: \mathrm{C}, 51.78 ; \mathrm{H}, 4.80 ; \mathrm{N}, 3.18$. Found: $\mathrm{C}$, $51.89 ; \mathrm{H}, 4.74 ; \mathrm{N}, 3.29 \%$.

\subsubsection{Complex $\boldsymbol{1}_{\boldsymbol{f}}$}

Yellow solid (76\%): IR (KBr): $1588 \mathrm{~cm}^{-1}\left(v_{\mathrm{C}=\mathrm{N}}\right) ;{ }^{1} \mathrm{H}$ NMR $\left(\mathrm{CDCl}_{3}, 400 \mathrm{MHz}\right): \delta 8.10(\mathrm{~s}, 1 \mathrm{H},-\mathrm{HC}=\mathrm{N}), 7.31$ (t, $J=7.8 \mathrm{~Hz}, 1 \mathrm{H}$, Ar H) $7.20-7.10(\mathrm{~m}, 3 \mathrm{H}, \mathrm{Ar} \mathrm{H}), 7.11$ (d, $J=7.8 \mathrm{~Hz}, 1 \mathrm{H}, \operatorname{Ar} \mathrm{H}), 6.87(\mathrm{t}, J=7.8 \mathrm{~Hz}, 1 \mathrm{H}, \mathrm{Ar}$ H), 3.49 (sept., $J=6.9 \mathrm{~Hz}, 2 \mathrm{H},-\mathrm{CH}), 1.36$ (d, $J=6.9$ $\mathrm{Hz}, 6 \mathrm{H},-\mathrm{Me}), 1.15(\mathrm{~d}, J=6.9 \mathrm{~Hz}, 6 \mathrm{H},-\mathrm{Me}) ; \mathrm{FAB} m / z$ : $933.0\left(\mathrm{M}^{+}-\mathrm{Cl}^{-}\right)$. Anal. Calc. for $\mathrm{C}_{38} \mathrm{H}_{42} \mathrm{Br}_{2} \mathrm{Cl}_{2} \mathrm{~N}_{2} \mathrm{Pd}_{2}$ : C, 47.04; H, 4.36; N, 2.89. Found: C, 46.90; H, 4.26; N, $2.85 \%$.

\subsubsection{Complex $\boldsymbol{4}_{g}$}

Brown solid $(95 \%)$ : IR $(\mathrm{KBr}): 1612 \mathrm{~cm}^{-1}\left(v_{\mathrm{C}=\mathrm{N}}\right) ;{ }^{1} \mathrm{H}$ NMR $\left(\mathrm{CDCl}_{3}, 400 \mathrm{MHz}\right): \delta 9.41(\mathrm{~s}, 1 \mathrm{H},-\mathrm{HC}=\mathrm{N}), 7.46$ $(\mathrm{d}, J=7.5 \mathrm{~Hz}, 1 \mathrm{H}$, Ar H), 7.39 (dd, $J=7.5 \mathrm{~Hz}, 7.5 \mathrm{~Hz}$ $1 \mathrm{H}, \operatorname{Ar} \mathrm{H}), 7.09$ (d, $J=7.5 \mathrm{~Hz}, 1 \mathrm{H}, \operatorname{Ar} \mathrm{H}), 4.81$ (sept., $J=6.7 \mathrm{~Hz}, 1 \mathrm{H},-\mathrm{CH}), 3.54$ (s, 3H, $-\mathrm{OMe}$ ), 2.91 (sept.,
$J=6.7 \mathrm{~Hz}, 1 \mathrm{H},-\mathrm{CH}), 2.20(\mathrm{~d}, J=6.7 \mathrm{~Hz}, 3 \mathrm{H},-\mathrm{Me})$, $1.97(\mathrm{~s}, 3 \mathrm{H},-\mathrm{Me}), 1.36(\mathrm{~d}, J=6.7 \mathrm{~Hz}, 3 \mathrm{H},-\mathrm{Me}), 1.31$ $(\mathrm{d}, J=6.7 \mathrm{~Hz}, 3 \mathrm{H}, \mathrm{Me}), 1.15(\mathrm{~s}, 18 \mathrm{H}, \mathrm{Me}), 0.26(\mathrm{~d}$, $J=6.7 \mathrm{~Hz}, 3 \mathrm{H}, \mathrm{Me}) ;{ }^{13} \mathrm{C}$ NMR: $\delta 185.4,176.1,164.0$, $144.3,143.6,141.6,140.2$, 128.2, 127.0, 125.0, 124.7, $64.4,35.7,31.5,29.2,28.5,26.4,24.8,24.1,23.9,22.8$; FAB $m / z: 1181.4 \quad\left(\mathrm{M}^{+}-\mathrm{Cl}^{-}\right)$. Anal. Calc. for $\mathrm{C}_{60} \mathrm{H}_{88} \mathrm{Cl}_{2} \mathrm{~N}_{2} \mathrm{O}_{6} \mathrm{Pd}_{2} \cdot \mathrm{H}_{2} \mathrm{O}: \mathrm{C}, 58.35 ; \mathrm{H}, 7.34 ; \mathrm{N}, 2.27$. Found: C, 58.63; H, 7.12; N, 2.06\%.

\subsubsection{Complex $\boldsymbol{3}_{\boldsymbol{h}}$}

Brown solid (77\%): IR (KBr): $1613 \mathrm{~cm}^{-1}\left(v_{\mathrm{C}=\mathrm{N}}\right) ;{ }^{1} \mathrm{H}$ $\mathrm{NMR}\left(\mathrm{CDCl}_{3}, 400 \mathrm{MHz}\right): \delta 9.32(\mathrm{~s}, 1 \mathrm{H},-\mathrm{HC}=\mathrm{N}), 7.25$ $(\mathrm{d}, J=7.5 \mathrm{~Hz}, 1 \mathrm{H}, \operatorname{Ar} \mathrm{H}), 7.17(\mathrm{dd}, J=7.5 \mathrm{~Hz}, J=7.5$ $\mathrm{Hz}, 1 \mathrm{H}, \mathrm{Ar} \mathrm{H}), 7.13$ (s, 2H, Ar H), 7.03 (d, $J=7.5 \mathrm{~Hz}$, $1 \mathrm{H}, \mathrm{Ar} \mathrm{H}), 3.61$ (s, 3H, -OMe), 2.88 (s, 3H, -Me), 2.11 (s, 3H, $-\mathrm{Me}), 1.76$ (s, 3H, -Me), 1.27 (s, $18 \mathrm{H}, \mathrm{Me}) ;{ }^{13} \mathrm{C}$ NMR $\left(\mathrm{CDCl}_{3}, 100 \mathrm{MHz}\right): \delta 184.6,176.0,163.9,144.5$, 144.3, 131.6, 131.1, 129.8, 129.4,s 128.7, 127.5,126.6, 64.4, 35.7, 31.6, 23.1, 20.0, 18.4; FAB $m / z: 1044.3\left(\mathrm{M}^{+}-\right.$ $\mathrm{OAc}^{-}$). Anal. Calc. for $\mathrm{C}_{52} \mathrm{H}_{72} \mathrm{Cl}_{2} \mathrm{~N}_{2} \mathrm{O}_{6} \mathrm{Pd}_{2} \cdot \mathrm{H}_{2} \mathrm{O}$ : C, $55.62 ; \mathrm{H}, 6.64 ; \mathrm{N}, 2.49$. Found: C, 55.66; H, 6.63; N, $2.38 \%$.

\subsubsection{Complex $\mathbf{3}_{\boldsymbol{h}}^{\prime}$}

Yellow solid (20\%): IR (KBr): $1613 \mathrm{~cm}^{-1}\left(v_{\mathrm{C}=\mathrm{N}}\right) ;{ }^{1} \mathrm{H}$ $\mathrm{NMR}\left(\mathrm{CDCl}_{3}, 400 \mathrm{MHz}\right): \delta 8.81(\mathrm{~s}, 1 \mathrm{H},-\mathrm{HC}=\mathrm{N}), 7.07$ (brs, 3H, Ar H), 6.92 (s, 2H, Ar H), 3.58 (s, 3H, -OMe), 2.38 (s, 6H, -Me), 1.18 (s, $18 \mathrm{H}, \mathrm{Me}) ;{ }^{13} \mathrm{C} \mathrm{NMR}\left(\mathrm{CDCl}_{3}\right.$, $100 \mathrm{MHz}): \delta 173.8,163.8,146.0,144.5,130.8,130.0$, 128.9, 127.2, 126.9, 64.3, 35.7, 31.5, 19.8. Anal. Calc. for $\mathrm{C}_{48} \mathrm{H}_{66} \mathrm{Cl}_{4} \mathrm{~N}_{2} \mathrm{O}_{2} \mathrm{Pd}_{2}: \mathrm{C}, 54.51 ; \mathrm{H}, 5.97 ; \mathrm{N}, 2.33$. Found: C, 53.98; H, 5.97; N, 2.33\%.

\subsubsection{Complex $7_{i}$}

Brown solid (55\%): IR (KBr) $1595 \mathrm{~cm}^{-1}\left(v_{\mathrm{C}=\mathrm{N}}\right) ;{ }^{1} \mathrm{H}$ NMR $\left(\mathrm{CDCl}_{3}, 400 \mathrm{MHz}\right): \delta 8.05(\mathrm{~s}, 1 \mathrm{H},-\mathrm{HC}=\mathrm{N}), 7.79$ $(\mathrm{d}, J=8.4 \mathrm{~Hz}, 1 \mathrm{H}, \mathrm{Ar} \mathrm{H}), 7.10(\mathrm{t}, J=8.4 \mathrm{~Hz}, 1 \mathrm{H}, \mathrm{Ar}$ $\mathrm{H}), 6.87(\mathrm{~d}, J=8.4 \mathrm{~Hz}, 1 \mathrm{H}, \mathrm{Ar} \mathrm{H}), 6.75(\mathrm{~s}, 1 \mathrm{H}, \mathrm{Ar} \mathrm{H})$, $6.54(\mathrm{~s}, 1 \mathrm{H}, \operatorname{Ar~H}), 6.45(\mathrm{t}, J=8.4 \mathrm{~Hz}, 1 \mathrm{H}, \operatorname{Ar~H}), 3.40$ $\left(\mathrm{d}, J=13.6 \mathrm{~Hz}, 1 \mathrm{H},-\mathrm{H}_{2} \mathrm{C}-\mathrm{Pd}\right), 2.52(\mathrm{~d}, J=13.6 \mathrm{~Hz}$, $\left.1 \mathrm{H},-\mathrm{H}_{2} \mathrm{C}-\mathrm{Pd}\right), 2.24$ (s, 3H, $\left.-\mathrm{Me}\right), 2.23(\mathrm{~s}, 3 \mathrm{H},-\mathrm{Me}) ;{ }^{13} \mathrm{C}$ NMR: $\delta$ 163.7, 147.0, 146.5, 139.9, 139.5, 139.4, 130.1, 129.8, 127.6, 127.5, 123.2, 115.3, 114.7, 21.4, 21.3, 20.5; FAB $m / z$ : $1374.2 \quad\left(\mathrm{M}^{+}\right)$. Anal. Calc. for $\mathrm{C}_{64} \mathrm{H}_{60} \mathrm{~N}_{4} \mathrm{O}_{4} \mathrm{Pd}_{4}: \mathrm{C}, 55.91 ; \mathrm{H}, 4.40 ; \mathrm{N}, 4.08$. Found: $\mathrm{C}$, $56.17 ; \mathrm{H}, 4.34 ; \mathrm{N}, 4.10 \%$.

\subsection{X-ray crystallographic analysis}

Crystals suitable for X-ray determination were obtained for $\mathbf{1}_{\mathrm{a}}$, trans- $\mathbf{1}_{\mathrm{b}}$, cis- $\mathbf{1}_{\mathrm{b}}, \mathbf{1}_{\mathbf{d}}, \mathbf{3}_{\mathrm{g}}$ and $\mathbf{7}_{\mathbf{i}}$ by re-crystallization at room temperature. Cell parameters were determined either by a Siemens SMART CCD diffractometer. Crystal data of the complexes $\mathbf{1}_{\mathbf{a}}$, trans $-\mathbf{1}_{\mathbf{b}}$, cis$\mathbf{1}_{\mathbf{b}}, \mathbf{1}_{\mathbf{d}}, \mathbf{3}_{\mathrm{g}}$ are listed in Table 5, whereas the complex 
Table 5

Selected crystallographic data of complexes $\mathbf{1}_{\mathbf{a}}$, cis- $\mathbf{1}_{\mathbf{b}}$, trans $-\mathbf{1}_{\mathbf{b}}, \mathbf{1}_{\mathbf{d}}$ and $\mathbf{3}_{\mathrm{g}}$

\begin{tabular}{|c|c|c|c|c|c|}
\hline Complex & $\mathbf{1}_{\mathrm{a}}$ & cis $-\mathbf{1}_{\mathbf{b}} /$ trans $-\mathbf{1}_{\mathbf{b}}$ & trans $-\mathbf{1}_{\mathbf{b}}$ & $\mathbf{1}_{\mathrm{d}}$ & $3 \mathrm{~g}$ \\
\hline Formula & $\mathrm{C}_{19} \mathrm{H}_{22} \mathrm{ClNPd}$ & $\mathrm{C}_{63} \mathrm{H}_{79} \mathrm{Cl}_{2} \mathrm{~N}_{3} \mathrm{O}_{7} \mathrm{Pd}_{3}$ & $\mathrm{C}_{25} \mathrm{H}_{34} \mathrm{ClNO}_{3} \mathrm{Pd}$ & $\mathrm{C}_{72} \mathrm{H}_{80} \mathrm{Cl}_{6} \mathrm{~N}_{2} \mathrm{O}_{8} \mathrm{Pd}_{2}$ & $\mathrm{C}_{60} \mathrm{H}_{88} \mathrm{Cl}_{2} \mathrm{~N}_{2} \mathrm{O}_{6} \mathrm{Pd}_{2}$ \\
\hline Formula weight & 406.23 & 1380.39 & 538.38 & 1526.88 & 1217.02 \\
\hline Crystal system & Monoclinic & Triclinic & Monoclinic & Triclinic & Monoclinic \\
\hline Space group & $P 2_{1} / c$ & $P \overline{1}$ & $P 2_{1} / n$ & $P \overline{1}$ & $P 2_{1} / c$ \\
\hline$a(\AA)$ & $11.100(1)$ & $13.0160(2)$ & $11.3480(1)$ & $11.0260(1)$ & $11.2648(2)$ \\
\hline$b(\AA)$ & $10.321(1)$ & $13.2052(2)$ & $18.4890(2)$ & $13.8190(2)$ & $45.3399(8)$ \\
\hline$c(\AA)$ & $16.724(2)$ & $19.9799(2)$ & $12.2610(1)$ & $13.8230(2)$ & $12.5379(2)$ \\
\hline$\alpha\left({ }^{\circ}\right)$ & 90 & $90.214(3)$ & 90 & $69.447(1)$ & 90 \\
\hline$\beta\left(^{\circ}\right)$ & $104.828(2)$ & $107 / 806(3)$ & $90.546(1)$ & $68.661(1)$ & $111.9727(6)$ \\
\hline$\gamma\left({ }^{\circ}\right)$ & 90 & $105.478(3)$ & 90 & $69.886(1)$ & 90 \\
\hline$V\left(\AA^{3}\right)$ & $1852.1(3)$ & $3137.38(7)$ & $2572.40(4)$ & $1779.62(4)$ & $5938.5(2)$ \\
\hline$Z$ & 4 & 2 & 4 & 1 & 4 \\
\hline$D_{\text {calcd }}\left(\mathrm{Mg} / \mathrm{m}^{3}\right)$ & 1.457 & 1.461 & 1.390 & 1.425 & 1.361 \\
\hline$F(000)$ & 824 & 1412 & 1112 & 784 & 2544 \\
\hline Crystal size (mm) & $0.20 \times 0.20 \times 0.35$ & $0.25 \times 0.20 \times 0.20$ & $0.30 \times 0.20 \times 0.20$ & $0.25 \times 0.20 \times 0.15$ & $0.12 \times 0.06 \times 0.01$ \\
\hline$\theta$ range $\left(^{\circ}\right)$ & $1.90-27.50$ & $1.08-25.00$ & $1.99-25.00$ & $1.64-27.49$ & $2.97-25.00$ \\
\hline Reflection collected & 24923 & 20080 & 15395 & 27363 & 45221 \\
\hline $\begin{array}{l}\text { Independent reflection } \\
\left(R_{\text {int }}\right)\end{array}$ & $4264(0.0234)$ & $11050(0.0444)$ & $4518(0.0247)$ & $8143(0.0563)$ & $10390(0.1352)$ \\
\hline Refined method & \multicolumn{5}{|c|}{ Full-matrix least-squares on $F^{2}$} \\
\hline$R[I>2 \sigma(I)]$ & $\begin{array}{l}R_{1}=0.0193 \\
w R_{2}=0.0480\end{array}$ & $\begin{array}{l}R_{1}=0.0437 \\
w R_{2}=0.1030\end{array}$ & $\begin{array}{l}R_{1}=0.0302 \\
w R_{2}=0.0782\end{array}$ & $\begin{array}{l}R_{1}=0.0426 \\
w R_{2}=0.1046\end{array}$ & $\begin{array}{l}R_{1}=0.0783 \\
w R_{2}=0.1504\end{array}$ \\
\hline Goodness-of-fit on $F^{2}$ & 1.052 & 1.078 & 1.177 & 1.041 & 1.073 \\
\hline
\end{tabular}

$7_{\mathbf{i}}\left(1 / 2 \mathrm{CH}_{2} \mathrm{Cl}_{2}\right): \mathrm{C}_{64.5} \mathrm{H}_{61} \mathrm{ClN}_{4} \mathrm{O}_{4} \mathrm{Pd}_{4}$, formula weight $=$ 1417.22, monoclinic, $P 2_{1} / c, a=18.5390(3) \AA, b=$ 17.1879(1) $\AA, c=19.5987(3) \AA, \alpha=90^{\circ}, \beta=116.85^{\circ}$, $\gamma=90^{\circ}, V=5571.9(1) \AA^{3}, Z=4, D_{\text {calcd }}=1.689 \mathrm{Mg} /$ $\mathrm{m}^{3}, \quad F(000)=2836, \quad 0.25 \times 0.08 \times 0.07 \mathrm{~mm}, \quad \theta=$ $1.23-27.50^{\circ}, 12488$ independent reflections out of 34941 reflections collected, $R_{1}=0.0513, w R_{2}=0.0951$ for $[I>2 \sigma(I)]$, goodness-of-fit on $F^{2} 1.107$. Other crystallographic data are deposited as supporting information.

\section{Supplementary material}

Crystallographic data (excluding structure factors) for the structure reported in this work have been deposited with the Cambridge Crystallographic Data Center: CCDC-222403 for $\mathbf{1}_{\mathbf{a}}$, CCDC-222404 for cis-1 $\mathbf{1}_{\mathbf{b}} /$ trans $-\mathbf{1}_{\mathbf{b}}$, CCDC-222405 for trans-1 $\mathbf{1}_{\mathbf{b}}$, CCDC-222406 for $\mathbf{1}_{\mathrm{d}}$, CCDC-222407 for $\mathbf{3}_{\mathrm{g}}$ and CCDC-222408 for $\mathbf{7}_{\mathbf{i}} \cdot 1 /$ $2 \mathrm{CH}_{2} \mathrm{Cl}_{2}$. Copies of this information can be obtained free of charge and by application to CCDC, 12 Union Road, Cambridge CB2 1EZ, UK (fax: +44-1223/336033; e-mail: deposit@ccdc.cam.ac.uk or www: http://www. ccdc.cam.ac.uk).

\section{Acknowledgements}

We thank the National Science Council, Taiwan, ROC for the financial support.

\section{References}

[1] (a) A.D. Ryabov, Chem. Rev. 90 (1990) 403;

(b) M. Pfeffer, Recl. Trav. Chim. Pays Bas. 109 (1990) 567;

(c) J. Albert, J. Granell, Trends Organomet. Chem. 3 (1999) 99, and references therein.

[2] (a) M. Gómez, J. Granell, M. Martinez, J. Chem. Soc., Dalton Trans. (1998) 37;

(b) A.D. Ryabov, I.K. Sakondinskaya, A.K. Yatsimirski, J. Chem. Soc., Dalton Trans. (1985) 2629;

(c) A.D. Ryabov, A.K. Yatsimirski, Inorg. Chem. 23 (1984) 789; (d) A.D. Ryabov, Inorg. Chem. 26 (1987) 1252, and references therein.

[3] (a) Recent studies of cyclopalladation with N-donors V.V. Dunina, O.N. Gorunova, E.B. Averina, Y.K. Grishin, L.G. Kuz'mina, J.A.K. Howard, J. Organomet. Chem. 603 (2000) 138; (b) A.J. Canty, J. Patel, B.W. Skelton, A.H. White, J. Organomet. Chem. 607 (2000) 194;

(c) R. Mosteiro, E. Perille, A. Fernandez, M. López-Torres, J.M. Vila, A. Suárez, J.M. Ortigueira, M.T. Pereira, J.J. Fernández, Appl. Organomet. Chem. 14 (2000) 634;

(d) A. Zucca, M.A. Cinellu, M.V. Pinna, S. Stoccoro, G. Minghetti, M. Manassero, M. Sansoni, Organometallics 19 (2000) 4295;

(e) V.V. Dunina, L.G. Kuz'mina, E.D. Razmyslova, V.P. Kislyi, Chem. Heterocycl. Compd. 35 (1999) 1001;

(f) Z.A. Bayir, O. Bekaroglu, Transition Met. Chem. 25 (2000) 404 ;

(g) A. Arques, P. Molina, D. Auñón, M.J. Vilaplana, M.D. Velasco, F. Martinez, D. Bautista, F.J. Lahoz, J. Organomet. Chem. 598 (2000) 329;

(h) J.M. Brunel, A. Heumann, G. Buono, Angew. Chem. Int. Ed. 39 (2000) 1946;

(i) D.J. Saccomando, C. Black, G.W.V. Cave, D.P. Lydon, J.P. Rourke, J. Organomet. Chem. 601 (2000) 305;

(j) M. Lousame, A. Fernandez, M. López-Torres, D. Vásquez- 
García, J.M. Vila, A. Suárez, J.M. Ortigueira, J.J. Fernández, Eur. J. Inorg. Chem. (2000) 2055;

(k) I.P. Smoliakova, K.J. Keuseman, D.C. Haagenson, D.M. Wellmann, P.B. Colligan, N.A. Kataeva, A.V. Churakov, L.G. Kuz'mina, V.V. Dunina, J. Organomet. Chem. 603 (2000) 86; (1) G. Minghetti, A. Doppiu, A. Zucca, S. Stoccoro, M.A. Cinellu, M. Manassero, M. Sansoni, Chem. Heterocycl. Compd. 35 (1999) 992;

(m) A. Lei, X. Lu, Org. Lett. 2 (2000) 2699;

(n) S.-W. Lai, T.-C. Cheung, M.C.W. Chan, K.-K. Cheung, S.-M. Peng, C.-M. Che, Inorg. Chem. 39 (2000) 255;

(o) J. Vicente, I. Saura-Llamas, J. Turpín, M.C. Ramírez de Arellano, P.G. Jones, Organometallics 18 (1999) 2683;

(p) D.J. Cardenas, A.M. Echavarren, M.C. Ramirez de Arellano, Organometallics 18 (1999) 3337;

(q) F. Cohen, L.E. Overman, Tetrahedron: Asymmetry 9 (1998) 3213 ;

(r) A. Caubet, C. López, R. Bosque, X. Solans, M. Font-Bardia, J. Organomet. Chem. 577 (1999) 292;

(s) Y. Fuchita, K. Yoshinaga, T. Hanaki, H. Kawano, J. Kinoshita-Nagaoka, J. Organomet. Chem. 580 (1999) 273;

(t) R. Bosque, C. López, Polyhedron 18 (1998) 135.

[4] A. Zucca, M.A. Cinellu, M.V. Pinna, S. Stoccoro, G. Minghetti, Organometallics 19 (2000) 4295.

[5] (a) M. Gomez, J. Granell, M. Martinez, Eur. J. Inorg. Chem. (2000) 217

(b) J. Albert, R. Bosque, J. Granell, R. Tavera, J. Organomet. Chem. 595 (2000) 54
[6] T. Yagyu, S. Iwatsuki, S. Aizawa, S. Funahashi, Bull. Chem. Soc. Jpn. 71 (1998) 1857.

[7] J.M. Vila, T. Pereira, J.M. Ortigueira, A. Amoedo, M. Graña, G. Alberdi, M. López-Torres, A. Fernández, J. Organomet. Chem. 663 (2002) 239

[8] (a) P. Braunstein, J. Fischer, D. Matt, M. Pfeffer, J. Am. Chem. Soc. 106 (1984) 410;

(b) M. Pfeffer, E. Wehman, G. van Koten, J. Organomet. Chem. 282 (1985) 127.

[9] A. Crispini, G.D. Munno, M. Ghedini, F. Neve, J. Organomet. Chem. 427 (1992) 409.

[10] (a) R.L. Garzon, D.G. Valero, C.V. Calahorro, N.C. Perez, A.G. Rodriguez, Monatsh. Chem. 118 (1987) 553;

(b) S. Ogoshi, T. Nishida, K. Tsutsumi, M. Ooi, T. Shinagawa, T. Akasaka, M. Yamane, H. Kurosawa, J. Am. Chem. Soc. 123 (2001) 3223;

(c) S. Ogoshi, K. Tsutsumi, T. Shinagawa, K. Kakiuchi, H. Kurosawa, Chem. Lett. (1999) 123.

[11] (a) H. Yang, M.A. Khan, K.M. Nicholas, J. Chem. Soc., Chem. Commun. (1992) 210;

(b) S.B. Sembiring, S.B. Colbran, D.C. Craig, M.L. Scudder, J. Chem. Soc., Dalton Trans. (1995) 3731;

(c) J. Vicente, J.-A. Abad, W. Förtsch, P.G. Jones, A.K. Fischer, Organometallics 20 (2001) 2704.

[12] G. Verardo, A.G. Giumanini, P. Strazzolini, M. Poiana, Synthesis (1993) 121.

[13] M. Girard, D.B. Moir, J.W. Apsimon, Can. J. Chem. 65 (1987) 189. 